\title{
Biological, environmental and socioeconomic threats to citrus lime production
}

\author{
Philip Donkersley $^{1}$ (1) $\cdot$ Farley W. S. Silva ${ }^{1} \cdot$ Claudine M. Carvalho $^{2} \cdot$ Abdullah M. Al-Sadi $^{3} \cdot$ Simon L. Elliot $^{1}$
}

Received: 17 August 2017 / Accepted: 9 March 2018/Published online: 21 March 2018

(C) The Author(s) 2018

\begin{abstract}
Limes as a fruit crop are of great economic importance, key to Asian and South American cuisines and cultivated in nearly all tropical and subtropical regions of the world. Demand for limes is increasing, driven by World Health Organization recommendations. Pests and pathogens have significantly reduced global productivity, while changes in agronomic techniques aim to alleviate this stress. We present here a holistic examination of the major biotic (pests and pathogens) and abiotic (environment and socioeconomic) factors that presently limit global production of lime. The major producers of limes are India, China and Mexico, while loss of lime production in the United States from 2006 has led many countries in the Western Hemisphere (Mexico, Costa Rica and Brazil) to export primarily to the USA. The most widespread invertebrate pests of lime are Toxoptera citricida and Scirtothrips citri. Another insect, Diaphorina citri, vectors both Huanglongbing (HLB) and Witches Broom of Lime, which are particularly destructive diseases. Developing agronomic techniques focus on production of resistant and pathogen-free planting materials and control of insect vectors. HLB infects citrus in nearly all growing regions, and has been particularly devastating in Asian citrus. Meanwhile, Citrus tristeza virus has infected over 100 million citrus trees, mainly in the Americas and Mediterranean. Currently, Witches Broom Disease of Lime is localised to the Middle East, but recently it has been detected in South America. The range of its vectors (D. citri and Hishimonus phycitis) further raises concerns about the potential spread of this disease. Abiotic threats to lime production are also a significant concern; key areas of lime production such as Mexico, India and the Middle East suffer from increasing water stress and high soil salinity, which combined with invasive pests and pathogens, may eliminate lime production in these areas. To ensure future security in lime production, policy makers, researchers and growers will need to examine the potential of more resistant lime cultivars and establish novel areas of cultivation.
\end{abstract}

Keywords Insect vectors · Citrus aurantiifolia $\cdot$ Acid lime $\cdot$ Pest distributions · Pathogens · Soil salinity · Water stress

Electronic supplementary material The online version of this article (https://doi.org/10.1007/s41348-018-0160-x) contains supplementary material, which is available to authorized users.

Philip Donkersley

donkersleyp@gmail.com

1 Department of Entomology, Universidade Federal de Viçosa, Viçosa, Minas Gerais, Brazil

2 Department of Phytopathology, Universidade Federal de Viçosa, Viçosa, Minas Gerais, Brazil

3 Department of Crop Sciences, College of Agricultural and Marine Sciences, Sultan Qaboos University, PO Box 34, AlKhod 123, Muscat, Oman

\section{General Introduction}

Citrus is the world's principal fruit crop, with about 60 million megatons grown annually (FAO 2015). There are five groups of cultivated citrus: sweet oranges, madarins, grapefruit, pommelo and the oft-grouped lemons and limes (Saunt 1990). The purpose of this review is to focus on the state of food security in lime. While many studies (particularly the UN Food and Agriculture Organisation [FAO]) have grouped lemon and lime together, we consider the two separately where possible.

Lime is a hesperidium fruit in the family Rutaceae (Yadav et al. 2004), with three classifications: (1) sweet lime (Citrus limetta Risso), with cultivars such as "Indian sweet lime" (Samson 1986); (2) acid limes, including the 
globally predominant "Key" lime (Citrus aurantiifolia (Christm.) Swingle) and the larger Tahiti lime (Citrus $\times$ aurantiifolia var. latifolia (Tan.)) (Samson 1986), and (3) finger lime (Citrus australasica F.Muell.) that is native to Australia but is not widely cultivated (Mabberley 2004). Lime is cultivated in tropical, subtropical and temperate regions from $40^{\circ} \mathrm{N}$ to $40^{\circ} \mathrm{S}$ (Mendel 1969; Samson 1986; Mukhopadhyay 2004). Limes account for $\sim 5 \%$ of global citrus production (FAO 2015) and countries in the Middle East, as well as India, Pakistan, Brazil, Argentina and Mexico grow lime as a key part of their agricultural economies (Liu et al. 2012; Al-Yahyai et al. 2015). Production quantities and economic values of lime have fluctuated over the past 25 years (Fig. 1a), and shifting ranges of pests and pathogens of lime have played a key role in this. The following review considers lime production and aims to provide insights into the roles of biotic and abiotic threats. It is hoped that these insights may contribute to efforts to stabilise the global lime market.

\section{Nutritional and health benefits of lime}

Citrus aurantifolia is used in "common consumption" in many cultural cuisines and in juice production (Berry 2003). Citrus species are consumed mainly as fresh or raw

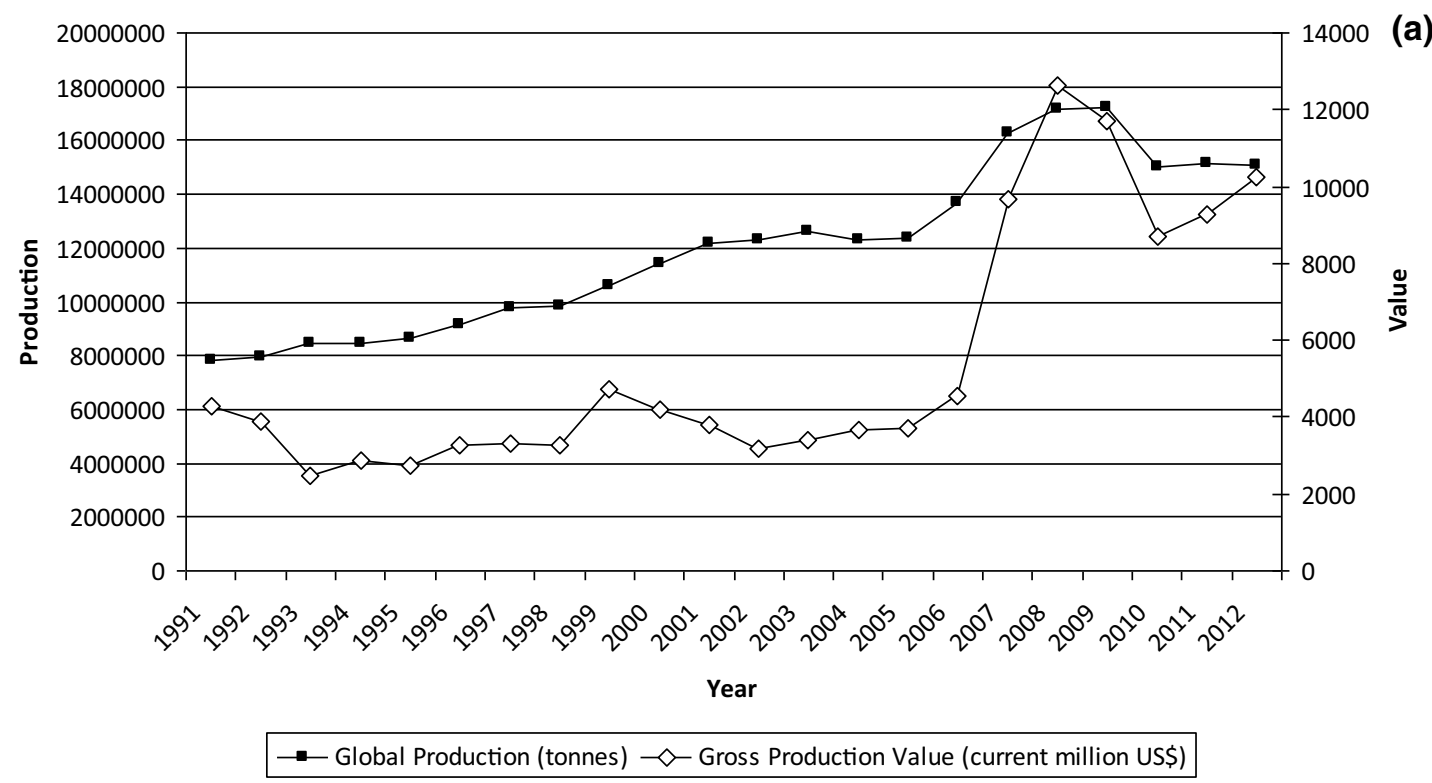

(b)

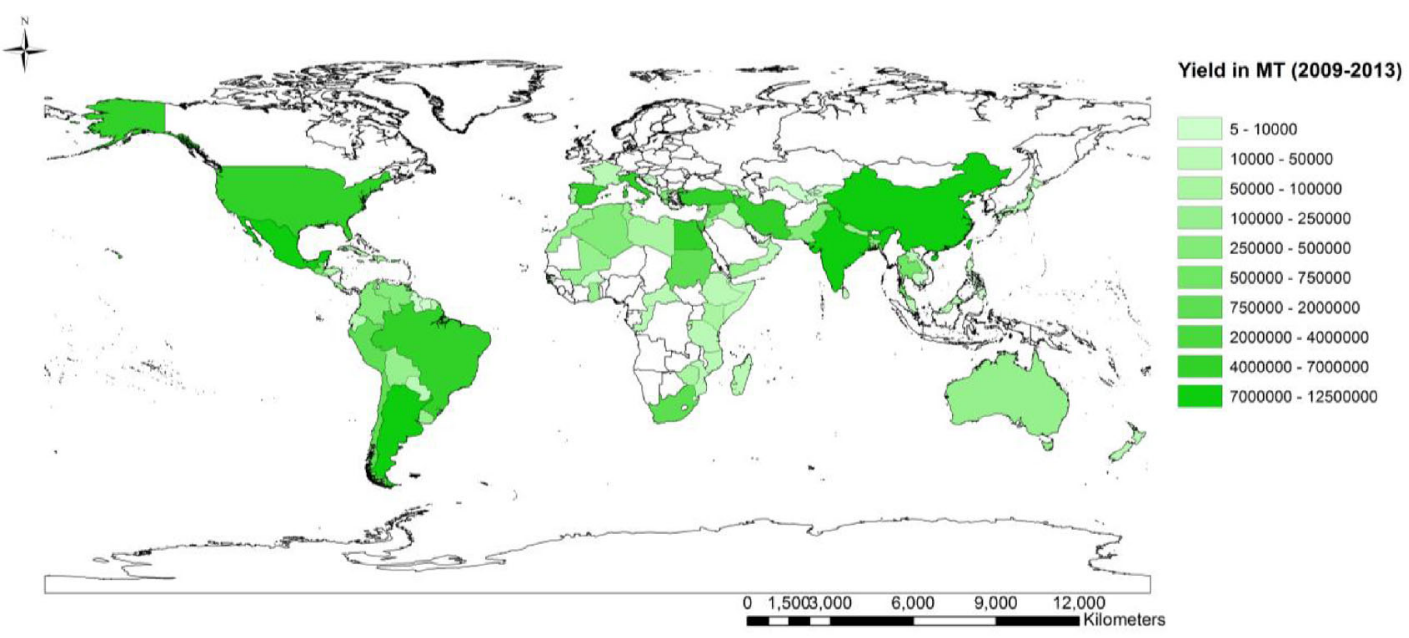

Fig. 1 a Global production (tonnes year ${ }^{-1}$ ) and economic value (US\$) of lemon and limes. b World's leading lime and lemon producers (Yield in MT). Source (FAO 2015) 
materials for juices or are canned as segments. Limes are a staple of South American and Asian cuisines and are used mainly for their juice, although lime zest and leaves are also used in cooking.

Citrus is well-known for its high vitamin $\mathrm{C}$ content, yet these fruits are also abundant in various macro- and micronutrients (Liu et al. 2012). The fruits are consumed for their macronutrients, such as carbohydrates and dietary fibre. The major carbohydrate constituents of citrus are sucrose, glucose, and fructose, generally in a ratio of 2:1:1 (McCready et al. 1950). Citrus fruits are a source of many micronutrients including thiamin, niacin, vitamin B6, riboflavin, potassium, calcium, magnesium, and copper (Economos and Clay 1999).

Although juice is the main commercial product of lemons and limes, essential oils are extracted and form a key part of the food industry. (Lota et al. 2002; Chisholm et al. 2003; Yadav et al. 2004). Limonene, an oil derivative of lime, is also used in the cosmetics industry and in household cleaning products such as soaps and detergents (Chisholm et al. 2003).

Citrus fruits have been used as traditional medicinal herbs in several Asian countries, such as China, Japan and Korea. Derivatives of lime are widely used for their antibacterial, anticancer, antidiabetic, antifungal, anti-hypertensive, anti-inflammation, and antioxidant properties (Narang and Jiraungkoorskul 2016).

\section{Current global market value of lime}

Global production and the economic value of limes has increased gradually from 1991 to 2006, with a significant increase in gross production value in 2006 (Fig. 1; (FAO 2015). The devastation of lime production in the USA following Hurricane Andrew (1992) and introduction of citrus canker and citrus greening diseases (see below) to the USA have been driving factors behind this. The US Government responded with a programme to eradicate infected citrus that lasted from 2002 to 2006, but this resulted in a substantial loss of lime production and an influx of imported limes at an inflated cost (Evans et al. 2014). As the USA is the principal driver of the global citrus market, accounting for $\sim 19 \%$ of total global trade, the loss of USA lime allowed rapid expansion of other markets, in particular that of Mexico, which now accounts for $>90 \%$ of limes imported to the USA (Evans et al. 2014). There was also a decrease in global production in 2010 , correlated with a significant decrease in production from China (FAO 2015).

\section{Key lime markets}

India, China, Mexico, Argentina and Brazil are the world's principal lime producing countries, and were together responsible for $60 \%$ of global production in 2009-2013 (Fig. 1b; FAO 2015). India is the largest producer of lime (Fig. 1b); citrus is the third most important fruit crop in India with an estimated total coverage of 1 million hectares (Ghosh et al. 2013). Acid lime (C. aurantiifolia) is the main cultivar produced in India, accounting for almost 20\% of total citrus production (Ghosh et al. 2013). By cultivated area, Mexico is another of the largest citrus-producing countries in the world (Spreen 2000); both sweet and acid limes are economically important in Mexico. As previously mentioned, Mexico is the primary source of limes imported to the USA, and therefore can be considered one of the world's most important lime markets (Plattner 2014).

Argentina and Brazil have the fourth and fifth largest markets of lemons and limes, respectively (FAO 2015); although Argentina temporarily surpassed India in 2006 with $19 \mathrm{MT} \mathrm{ha}^{-1}$ compared to $12.2 \mathrm{MT} \mathrm{ha}^{-1}(\mathrm{Mu}-$ nankarmi et al. 2014). Argentina primarily grows sweet lime, whereas in Brazil acid lime has traditionally been the principal cultivar. Across the Middle East, Turkey, Iran, Israel and Syria are also important producers of lime (Fig. 1b, FAO 2015). Finally, although China is reported by the FAO as a major producer of citrus, less than $4 \%$ of national citrus production is lemon and lime (Scott et al. 2012). In tropical countries where refrigeration in transport and storage is a constraint, acid lime (C. aurantiifolia) may be preferred due to its longer non-refrigerated shelf life (Spreen 2000).

\section{Major invertebrate pests and microbial pathogens of lime}

Citrus hosts a broad suite of invertebrate pests and microbial pathogens which have achieved near-pandemic distributions. Here, we focus on the pathogen-pest complex of lime that has caused severe economic losses in production. The following review addresses the distribution of citrus pests and pathogens, the potential damage posed by each and the predominant control methods. It is accompanied by a programme that displays, through temporal maps, shifting distributions of pests and pathogens of limes from 1960 to the present day (see Supplementary materials). Distribution data were collected through a literature search (citations with each pest below) and supplementary data were also collected from the Centre for Agriculture and Biosciences International (CABI) Invasive Species Compendium (CABI 2015). Due to the difficulties in 
accurately monitoring the distribution of plant pathogens, only two (Citrus liberibacter and Xanthomonus citri) had sufficient data on global distributions to warrant inclusion in the programme.

The arthropod pests of lime can be classified broadly into three categories based upon the principal injuries they cause: disease vectors, sap feeders and fruit feeders. Meanwhile, pathogens are classified taxonomically based on the aetiological agents that are known to cause the diseases: bacteria, viruses and fungi.

\section{Disease vectors}

\section{Asian citrus psyllid}

Diaphorina citri Kuwayama (Hemiptera: Psyllidae) originated in south-east Asia, New Caledonia and Australia (Swingle and Reece 1967; Liu and Tsai 2000), and has since spread to most of the citrus-growing areas of the world. It is widespread throughout southern parts of Asia, including India and Pakistan (Aubert 1987). This organism has also been detected in Iran, Saudi Arabia (Bové et al. 2000), Mexico and South America (Aubert 1987). Diaphorina citri is a vector of Huanglongbing (HLB; Aubert 1987), and is a vector of Witches' Broom Disease (WBDL; Queiroz et al. 2016), a phytoplasma-caused disease of lime (Texeira et al. 2005). As such, it is often the most serious pest of citrus (Grafton-Cardwell et al. 2013). If no pathogens are present, however, $D$. citri is usually a minor pest (Halbert and Manjunath 2004).

Chemical control of D. citri focuses primarily on preharvest applications of organophosphates and neonicotinoids as an effective control for D. citri (Dahiya et al. 1994). Furthermore, some success has been achieved with breeding lime cultivars that are resistant to feeding by $D$. citri (Westbrook et al. 2011). Biocontrol with the parasitoid Tamarixia radiata (Waterston) has been successful on islands with significant reductions in D. citri populations (Aubert 1987; Chien et al. 1989).

\section{Black citrus aphid}

Toxoptera citricida Kirkaldy (Hemiptera: Aphidae) is native to Asia and has subsequently become widely distributed on citrus in Florida, India, Australia, sub-Saharan Africa, Madagascar, Indian Ocean Islands and South America (CABI 2015). It is a major problem due to its efficient transmission of Citrus risteza virus (CTV), and has been largely responsible for the global distribution of CTV (Yokomi et al. 1994), although other aphid species have impacted certain localities of transmission (see "Viruses" section). Consequently, control has been focussed more on limiting transmission of the pathogen, particularly transport and use of CTV-infected tissue in nurseries (Garnsey et al. 1996; see "Citrus canker" section). Toxoptera citricida also transmits Citrus vein enation virus (Da Graça and Maharaj 1991).

\section{Leafhopper}

The centre of origin for Hishimonus phycitis (Distant) (Hemiptera: Cicadellidae) is uncertain; it was found feeding on citrus in Oman in 1991, then in the United Arab Emirates in 1993, and in Iran in 2000 (Bové et al. 2000). It has also been found in various citrus-growing regions of India and Pakistan as Cestius phycitis, now confirmed as $H$. phycitis (Sohi et al. 1974). Although physical damage by H. phycitis is comparable to other phloem-feeding organisms, as with $D$. citri and T. citricada the greatest concern is as a vector of various diseases (see Table S1; Salehi et al. 2007; Bagheri et al. 2009). Hishimonus phycitis can be controlled through applications of carbamate or pyrethroid insecticides, and eradication of weed-species pathogen refugia(Queiroz et al. 2016).

\section{Citrus longhorn beetle}

Anoplophora chinensis Forster (Coleoptera: Cerambycidae) originated in China, and is now distributed across most of south-east Asia (EPPO 2015) and has been detected in Europe since 2001 (Colombo and Limonta 2001). The main damage caused by this organism is indirect, via plant-pathogenic fungi that can colonise the damage caused by beetle burrowing. Organophosphate insecticide applications to tree canopies are used to kill adults, and at the base of the trunk to kill eggs and larvae (Hu et al. 2009). The entomopathogenic fungi, Beauveria bassiana and $B$. brongniartii have also been used effectively to control A. chinensis in Japan (Kashio and Ujiye 1988).

\section{Sap feeders}

\section{Citrus leaf miner}

Phyllocnistis citrella Stainton (Lepidoptera: Gracillariidae), the citrus leaf miner (CLM) is native to South and south-east Asia, extending from the Middle East to China, Korea and Japan (Heppner 1993). CLM spread to Africa and Australia in the early 1900's and later to all continents, arriving in North America in 1993 and South America in 1996 (Heppner 1993; EPPO 2015). Its arrival in North America, combined with the damage resulting from Hurricane Andrew have been suggested to represent a key turning point in the loss of lime production in Florida (Crane et al. 1993; Heppner 1993). CLM mines beneath the 
epidermis of young leaves, stems and fruits, ingesting the parenchyma and resulting in chlorotic patches on attacked tissues (Murai 1974; Legaspi et al. 1999). Chemical control by insecticides remains the most commonly used control method worldwide, while classical biological control methods using chalcid wasp parasitoids show potentially economically viable and effective alternatives (Argov and Rossler 1996; Schauff et al. 1998).

\section{Black and citricola scale}

Saissetia oleae Olivier (Hemiptera: Coccidae), black scale originated in South Africa (Lotto 1976) and now has a global distribution (Ben-Dov 1993). Coccus pseudomagnoliarum Kuwana (Hemiptera: Coccidae), Citricola scale is native to Asia and now also has a global distribution (Tena and Garcia-Marí 2008). The intermittent feeding habits and waxy dorsal surface make chemical control difficult; consequently, biopesticides, biological control and cultural practices have become the focus of their management in citrus (Grafton-Cardwell et al. 2006).

\section{Thrips}

Scirtothrips citri Moulton (Pterygota: Paraneoptera) is mostly known from Central and North America and has also been detected within nurseries in Iran (Akbari and Seraj 2007) and recently in China (EPPO 2015). Damage to fruits occurs in the first 3-6 weeks after petal fall, with heavily scarred fruits showing rapid weight loss, making them unmarketable (Morse and Brawner 1986; Arpaia and Morse 1991). Due to their size, mobility and fecundity, thrips are notoriously difficult to control; consequently, biological control using predatory mites is the most common means employed (Grafton-Cardwell et al. 1999).

\section{Citrus blackfly}

Aleurocanthus woglumi (Aleyrodidae, Ashby) originated from southern Asia and has spread to the Middle East, Caribbean, Central America and south-eastern areas of Africa (EPPO 2015). Damage by this pest is multifaceted: sap feeding, sooty mould growth resulting from honeydew secretions, such that $A$. woglumi infestations can reduce yield by up to $80 \%$ (Watts and Alam 1973). Chemical control of A. woglumi has limited success due to the waxy cuticle of early instars, but classical biological control of citrus blackfly has been achieved throughout much of its global range by a complex of hymenopteran parasitoids.

\section{Woolly whitefly}

Aleurothrixus floccosus (Aleyrodidae, Maskell) is another serious citrus pest across the world, reported in Africa (Giliomee and Millar 2009; Belay et al. 2011), Europe (Katsoyannos et al. 1997; Soto et al. 2002), Asia (Kanmiya and Sonobe 2002), North and South America (Miklasiewicz and Walker 1990). As with A. woglumi, adults and nymphs inflict direct damage to citrus by feeding on phloem, which can cause premature leaf fall at high infestations (Umeh and Adeyemi 2011). Much like other honeydew producing pests, indirect damage also comes from sooty mould growth after feeding. Chemical control of the woolly whitefly is sometimes difficult due. Thus, biological control may be an effective strategy against this pest, mainly with parasitoid wasps; Giliomee and Millar 2009; Mercado et al. 2014).

\section{Fruit feeders}

\section{Fruit flies (Diptera: Tephritidae)}

Fruit flies are generic pests of world fruit production and damage is primarily caused by the larvae consuming fruit pulp, resulting in unmarketable fruits (Baker 1944; McCoy et al. 2009). Five species of fruit flies pose a significant threat to citrus: the South American fruit fly (Anastrepha fraterculus Wiedemann), the West Indian fruit fly (Anastrepha obliqua Macquart), the Mexican fruit fly (Anastrepha ludens Loew), the Caribbean fruit fly (A. suspensa Loew) and the Mediterranean fruit fly (Ceratitis capitata Wiedemann). Ceratitis capitata is spread over several countries including: the USA, Brazil, Central America (Guatemala and Honduras), Africa (Nigeria, Mauritius and Morocco), Eurasia (Turkey) and Europe (Greece, Portugal and Spain) (Hendrichs et al. 1994; Agunloye 1987; Eskafi 1988; Obenland et al. 1998; Epsky et al. 1999; UchoaFernandes et al. 2003). The Anastrepha species have a narrower distribution, restricted to Central and South America, Mexico, the Caribbean and USA (Baker 1944; Boykin et al. 2006; Ruiz-Arce et al. 2015).

Fruit flies are important quarantine species; the detection of even a minor infestation makes all fruits grown in a citrus orchard internationally unmarketable (Heath et al. 2002). Entomopathogens are currently not an effective control, because they are incapable of providing sufficiently rapid population reduction (McCoy et al. 2009). Bait traps, combined with insecticides, are the main methods for detection and control of these pests (Balock and Fernando 1969; Manrakhan et al. 2015). Hymenopteran parasitoids (e.g. Braconidae) are also employed for integrated pest management in citrus orchards to 
maintain fruit fly populations below economic damage thresholds (Vargas et al. 2001).

\section{Acari: Mites}

Mites are key pests of citrus, causing feeding damage and vectoring phytopathogens. There are three families of mites that are particularly threatening to citrus: Eriophyidae, Tetranychidae and Tenuipalpidae.

\section{Eriophyid mites (Acari: Eriophyidae)}

Eriophyid mites, the citrus rust mites (Phyllocoptruta oleivora (Ashmead) and Tegolophus brunneus (Flechtmann)), infest leaves and citrus fruits and damage primarily by feeding (Flechtmann 1999; McCoy et al. 2009; Vacante 2010). Although eriophyid mites of citrus have a global distribution (Navia et al. 2009), the mites are more economically important in humid citrus-growing regions, such as Florida (USA), south-east Asia (Bergh 2001) and Brazil (Flechtmann 1999). Feeding destroys epidermal cells of leaves and fruit while plant tissues become blackened or rusted (McCoy and Albrigo 1975). These injuries reduce fruit size and increase fruit drop, negatively impacting market quality (Yang et al. 1994). Eriophyid mites are managed by chemical and biological control (Omoto et al. 1994). Predatory mites (Phytoseiidae and Stigmaeidae) have considerable potential as natural enemies. Eriophyid mites are, however, too small and low in nutritional content to be preferred by many predators and have escaping and hiding behaviours (Sabelis 1996).

\section{Tetranychid mites (Acari: Tetranychidae)}

Tetranychid mites feed on leaves, branches and fruits using piercing and sucking mouthparts. Some species, such as Panonychus citri (McGregor), Tetranychus urticae Koch and Eutetranychus orientalis (Klein), are capable of making protective webs and thus are known as "spider mites" (Vacante 2010). Tetranychids have a global distribution, with citrus pest species known to occur in both China and Brazil (Bolland et al. 1998). Acaricides are the primary control method for tetranychids, but biological control may also be used under integrated pest management (IPM) strategies. Predatory phytoseiid mites are demonstrably effective for controlling tetranychids in citrus and can significantly reduce damage to the plant (Abad-Moyano et al. 2010; Fadamiro et al. 2013). Coccinelid beetles (Stethorus and Parasthethorus) can be very effective in regulating mite populations at low densities and have been important in maintaining suppression of tetranychid populations in Asia (Carillo et al. 2012) and Peru (Guanilo and Martínez 2007).

\section{Tenuipalpid mites (Acari: Tenuipalpidae)}

Tenuipalpid mites are known as "false spider mites" as they lack the ability to make silk webs (Vacante 2010). The principal genus, Brevipalpus, is generally smaller than tetranychids (0.2-0.4 mm in length) (Childers 1994). Citrus pests within the tenuipalpids are primarily recorded in India, Pakistan and North America (Ghai and Shenhmar 1984). Although tenuipalpids are typically considered secondary pests of citrus, their capacity to vector plant viruses is a cause for concern (Rodrigues et al. 2003), notably in the case of Citrus leprosis virus (see below). Biological control of these mites is still at an early stage, so chemical control remains as the most efficient strategy (Vacante 2010; Van Leeuwen et al. 2015).

\section{Other invertebrates}

Citrus nematode (Tylenchulus semipenetrans, Tylenchulidae) is reported to be present in most citrus orchards globally (Irshad et al. 2012). The nematode attacks roots, causing "slow decline" disease of citrus. Citrus roots infested with the nematode are also readily colonised by the fungal pathogens Fusarium oxysporum and $F$. solani (Nemec 1978). Nematode infestations may occur without inducing any visible aboveground symptoms; belowground symptoms may include poor root growth, and soil adhering to roots giving them a dirty appearance (Irshad et al. 2012).

Nematodes can be managed through a combined use of cultural, chemical control and resistant rootstocks. Use of certified soils and fumigation of infested soils prior to planting can control nematode damage. Trifoliate orange and Troyer citrange rootstocks are tolerant to citrus nematode and are thus recommended for planting (Kaplan 1981).

\section{Huanglongbing}

Huanglongbing (HLB-translated "yellow dragon disease"), also known as citrus greening disease, was first described in south China (Bové 2006). The aetiological agent of HLB consists of a complex of three uncultured Liberibacter species given the "Candidatus" status. Thus, "Candidatus Liberibacter asiaticus" is known to occur across central Asia, South China and south-east Asia (Bové 2006), while "Candidatus Liberibacter africanus" has been found in South Africa and Zimbabwe and the two organisms have also been found co-existing in the same tree on both Mauritius and Réunion Island (Gasparoto et al. 2012). Finally, "Ca. Liberibacter americanus" has been found in the USA (Florida), Mexico and Brazil (São Paolo) and has a limited distribution across the Caribbean (da 
Graça 2004; Halbert and Núñez 2004; Gottwald et al. 2007).

HLB can be transmitted by grafting and by insect vectors including the psyllids Trioza erytreae (Del Guercio) and D. citri (Table S1; Gottwald et al. 2007). Although the distributions of these vectors mostly match the distribution of HLB, there are regions of Brazil and Australia where the vector is currently present without evidence of HLB (da Graça 2004). HLB has been described as the most destructive disease of citrus in the world (Bové 2006). HLB-infected trees show excessive fruit drop, while diseased fruits are small, lopsided and remain green (Bové 2006; Gottwald et al. 2007). Yield reduction can range from 30 to $100 \%$, rendering orchards economically inviable within 7-10 years (da Graça 2004; Bassanezi et al. 2009).

A suite of molecular tools exist for the identification of HLB: although conventional PCR targeting ribosomal protein L10 (rplJ) and L12 (rplL) intron sequences have been used (Wang et al. 2006), these methods have a poor sensitivity to low-titre level infections. Real-time quantitative PCR may be more reliable (Coy et al. 2014), and have demonstrated dynamic variation in titre levels across different seasons, with peaks occurring between October and December, and was troughs between March and May in southern China (Wang et al. 2006).

Controlling this pathogen is still further complicated by issues with monitoring, and a lack of success with breeding for resistance to HLB in C. aurantiifolia (Gottwald et al. 2007). Currently, the most effective programme of control of HLB has been demonstrated in South Africa with a combination of planting disease-free budwood and nursery trees, chemical control of psyllid vectors, and roguing (or removal) of infected trees (Le Roux et al. 2006; Gottwald et al. 2007).

\section{Witches' Broom Disease of Lime}

Symptoms of witches' broom disease of lime (WBDL) were first observed in Oman in the 1970s (Waller and Bridge 1978). It had spread to the United Arab Emirates (UAE) by 1989 and to south-eastern Iran by 1997 (Mardi et al. 2011). Similar strains of the phytoplasma have also been reported in the Nagpur region of India in 1999 (Ghosh et al. 1999). Currently in Oman, WBDL has been found in all lime growing regions, albeit with reduced infection rates in the south of the country (Al-Sadi et al. 2012). WBDL disease is caused by the unculturable "Candidatus Phytoplasma aurantifolia", belonging to the 16SrIIb Peanut Witches' Broom group; (Zreik et al. 1995). Phytoplasmas are cell wall-less, non-helical prokaryotes in the class Mollicutes that inhabit plant phloem. Molecular tools using the R16F2n/R16R2 (Lee et al. 1993), fU5/rU3 (Chen et al.
2009) and P1/P7 (Deng and Hiruki 1991) primer sets have been developed for identification of WBDL from field samples (Ghosh et al. 2013; Al-Yahyai et al. 2015). There are, therefore, inconsistencies in PCR amplification between different primer chemistries; in order to achieve a global consensus on the geographical distribution of this pathogen, a consensus on identification methods must be achieved.

The situation is particularly dire in the Middle East, as in a study from Oman in which an estimated $98 \%$ of $C$. aurantiifolia limes currently grown in Oman were found to be infected with WBDL (Al-Yahyai et al. 2015). The pathogen kills lime trees in less than 5 years and has become a major limiting factor for lime production in the Middle East (Bové and Garnier 2000; Chung et al. 2009). Although " $\mathrm{Ca}$. Phytoplasma aurantifolia" is capable of infecting other citrus species, successful infection of other lime species, including Tahiti limes (C. latifolia) and sweet lime (C. limetta) has yet to be demonstrated (Chung et al. 2009). Alternative cultivars such as these may have an important role in establishing disease-free areas for citrus industries destroyed by WBDL.

Both $H$. phycitis and $D$. citri have been demonstrated to be vectors of WBDL in C. aurantiifolia (Salehi et al. 2007; Queiroz et al. 2016); transmission through grafting of infected tissue has also been demonstrated (Ghosh et al. 2013) and nurseries are considered to be a major source of inoculum (A. Al-Sadi, pers. comm.). The rapid spread of infection by WBDL in Oman has been attributed to the low level of genetic diversity of acid lime and frequent exchange of infected planting material between districts (Al-Sadi et al. 2012). Therefore, restricting international movement of infected plant material and higher genetic diversity in new plantations will play an important role in restricting the international spread of this pathogen. There are currently very limited options for treating WBDL, some success has been demonstrated with a Bacillus subtilis derivative compound "surfactin", which has been shown to have an inhibitory effect on " $\mathrm{Ca}$. P. aurantifolia" (Askari et al. 2011). Despite its currently limited distribution, WBDL may cause serious threat to the citrus industry in future if not managed immediately (Ghosh et al. 2013; Silva et al. 2014).

\section{Citrus canker}

Citrus canker of lime refers to five different groups of gram-positive rod-shaped bacteria from Xanthomonas, which is distinguished by their geographical range, host specificity and symptoms. The most well-documented aetiological agent is Xanthomonas axonopodis pv. citri Hasse (Rodríguez et al. 1985), which distributed across all of Asia and South America, although it is notably absent 
from Mexico and eradicated in New Zealand and Australia (EPPO 2015).

Xanthomonas citri survives in diseased plant tissues from season to season and this is the primary inoculum source for new infections. The organism can survive as an epiphyte on host and non-host plants, and as a saprophyte on straw mulch or in soil (Chagas et al. 2001). Xanthomonas citri is disseminated by rainwater running over the surfaces of lesions and splashing onto uninfected shoots. The main losses to this disease occur through defoliation of young trees (Evans et al. 2014). Planting canker-resistant citrus is an essential first step to eradicating this disease (de Carvalho et al. 2015); currently infected trees, however, can only be effectively treated through rouging (Gonçalves-Zuliani et al. 2016) while control of spread to new areas can be managed by the implementation of strict international plant quarantine regulations.

\section{Viruses}

Citrus tristeza virus (CTV) is a member of genus Closterovirus (family Closteroviridae) and is considered as the most destructive viral disease of citrus, causing the death of infected trees of most citrus cultivars (particularly acid lime); to date over 100 million trees have been destroyed as a result of the disease, mainly in North and South America but also in some Mediterranean countries (Moreno et al. 2008; EPPO 2015). It is believed to have originated in China (Moreno et al. 2008) but is now widespread throughout tropical citrus-growing regions (Timmer et al. 2000). The black citrus aphid (T. citricida) is the main vector of CTV (Yokomi et al. 1994); of all cultivated citrus, acid lime is particularly sensitive to most CTV isolates (Roistacher 1991). Both dispersal of vectoring aphids and transport of infected budwood have been the most important factors influencing tristeza spread (Moreno et al. 2008). CTV control measures include rouging to eradicate infected tissues (Bar-Joseph et al. 1989; Moreno et al. 2008), quarantine and certification programmes (Navarro 1993), use of CTV resistant or tolerant rootstocks (Domínguez et al. 2000), or cross-protection with mild isolates (Sambade et al. 2002).

Citrus leprosy, caused by Citrus leprosis virus C (CLV; Family Rhabdoviridae), is transmitted by tenuipalpid mites (Rodrigues et al. 2003). It has only been reported within the Americas. The symptoms are characterised by chlorotic or necrotic lesions surrounded by a yellow halo and infections can cause $100 \%$ yield loss (Locali et al. 2003). CLV may be the most important viral disease in the Brazilian citrus industry (as CTV is under control) through the cost of controlling its vector, valued at about US $\$ 90$ million dollars per year (Locali et al. 2003).
Citrus yellow mosaic disease, caused by Citrus yellow mosaic virus (CYMV; Family Caulimoviridae), has a large economic impact on the citrus industry in India (Ahlawatl et al. 2005). Evidence suggests it is transmitted through infected rootstocks and by mealybugs (Planococcus citri (Risso); Ahlawatl et al. 2005). Novel molecular techniques are being developed to screen rootstock nurseries for infected trees (Kumar et al. 2015).

Citrus psorosis is a globally devastating disease of citrus caused by an infectious filamentous ophiovirus, Citrus psorosis virus (Achachi et al. 2014). Infected trees slowly decline and eventually become unproductive; the disease has damaged citrus production in the Mediterranean, and in Argentina and Uruguay; where it has caused annual losses of about 5\% of trees (Zanek et al. 2006). Psorosis is exclusively graft-transmitted, symptoms rarely appear before lime trees are 10 years old making this disease particularly problematic to control (Martín et al. 2002). Thermotherapy combined with healthy shoot-tip-grafting can be successful in obtaining a psorosis-free new plant (Carvalho et al. 2002).

Citrus sudden decline (CSD) has been identified in Minas Gerais state, Brazil in 2001 (Gimenes-Fernandes and Bassanezi 2001), caused by Citrus sudden death-associated virus (Tymoviridae: Marafivirus). The virus has no known vectors although it is likely spread by an aphid vector (Maccheroni et al. 2005); it is demonstrably grafttransmissible, and is often found in co-infections with CTV (Maccheroni et al. 2005; Bové and Ayres 2007). CSD primarily infects Rangpur lime and Volkamer lemon rootstocks (Bové and Ayres 2007); consequently, the spread of this pathogen may force the industry to rely more heavily on irrigation (see "Agronomy" section).

Another sudden decline disease associated with mango, date and lime has been growing in importance in Oman since 2006 (Al Adawi et al. 2006). The symptoms of the Omani Sudden Decline are reduced leaf growth, yellowing and necrosis followed by rapid death of the plant. Although a single aetiological agent has not yet been determined, it has been found associated with a complex of three different pathogens: 16SrII phytoplasma, Citrus tristeza virus (CTV) and Citrus exocortis Yucatan viroid (CEYVd) (Nascimento da Silva et al. 2015).

\section{Other pathogens}

Several other pathogens of citrus exist in mostly localised distributions, including Citrus Blast (Pseudomonas syringae $p v$. syringae), and several fungal infections: Anthracnose (Colletotrichum gloeosporioides), Melanose of citrus (Diaporthe citri), Black root rot (Thielaviopsis basicola) and Armillaria root rot (Armillaria mellea). Citrus blackspot (Guignardia citricarpa) currently has a 
very limited range but can cause significant damage to fruit marketability (Kotzé 1981). Citrus variegated chlorosis disease (CVC), caused by the bacterium Xylella fastidiosa, has been known to affect sweet orange in Brazil for at least 20 years Citrus pink disease, caused by the fungal pathogen Erythricium salmonicolor, is present in Brazil and Australia, primarily causing damage to the bark of trees, which may result in girdling (Timmer et al. 2000). Citrus scab fungus (Elsinoe fawcettii) causes fruit damage that reduce its value at market, it is confirmed present only in South America, but recent research suggests it may also be present in South Korea (Hyun et al. 2001). Phytophthora gummosis and root rot are damaging diseases around the world. Phytophthora diseases have a global distribution, and damage has primarily been concentrated in North America (Timmer et al. 1993; Matheron et al. 1997).

By combining distributions of the major invertebrate pests and pathogens that have detailed temporal distributions (see supplementary materials), we demonstrate that several key areas of lime production are, perhaps unsurprisingly dominated by high pest diversity (Fig. 2). Although each of these pests are of variable economic importance, increasing diversity of pests is clearly linked to complexity (and therefore difficulty) in crop protection methods. Highly pest diverse regions could be considered as more threatened. These distributions also reveal certain areas of citrus production that have lower pest diversity, such as New Zealand and Australia and the Mediterranean, which may be key areas to monitor for novel invasions of pest species.

\section{Agronomic and abiotic threats}

In addition to the issues caused by the pests and pathogens of lime, there may also be abiotic factors exacerbating losses in lime production, both globally and locally. Here, we focus on the environmental, socio-political and agronomic factors that are presently influencing lime agriculture and will exacerbate other previously mentioned biotic factors.

\section{Agronomy}

Limes may be cultivated in a number of different approaches. C. aurantifolia can be propagated from seed or propagated vegetatively from cuttings (Duke and duCellier 1993). The most common method globally is bud-grafting onto a selection of rootstocks (Castle 2010; see "Rootstock management" section). Citrus gummosis is particularly damaging to seedlings and appropriate rootstocks are often chosen according to this disease threat. Trees cultivated from seedlings take $4-8$ years before producing a harvest and reach maximal yield after 10 years. Trees grown from cuttings are economically viable sooner, and may produce fruit a year after planting (Duke and duCellier 1993).

Climatic conditions are critical for successful cultivation of limes: under consistently warm regions trees can be planted at any season, whereas in cooler temperate regions planting should be reserved for spring after ground frosts have ceased (Morton 1987).

Lime shelf life is an important consideration in postharvest marketing. Lime fruits continue to ripen for a considerable time after harvesting; they are usually refrigerated between 9 and $10{ }^{\circ} \mathrm{C}$ at a relative humidity of $>85 \%$ to limit degradation. There are several procedures to extend shelf life: applications of growth regulators such as calcium compounds or silver nitrate, waxing the fruit and fungicides sprays (Bisen et al. 2012). C. aurantiifolia has the longest post-harvest shelf life, making it the preferred cultivar (Spreen 2000).

\section{Soil nutrition and irrigation}

Soil conditions, irrigation and sufficient nutrient application are all important factors in producing quality citrus fruits (Levy and Syvertsen 2004). Nitrogen is the most important nutrient for citrus, demonstrating the most direct response from application to productivity (Tucker et al. 1995; Alva et al. 2003). Phosphorous is another key nutrient in citrus, where sufficient soil phosphorous levels influence non-structural carbohydrate pools in citrus (Graham et al. 1997). These pools include root-starch levels, which can determine successful establishment of root stocks, and fruit sugar content influencing harvest quality (Graham et al. 1997).

Most citrus production is at least partially dependent on irrigation for economic production (Levy and Syvertsen 2004). When well-managed, precision irrigation can maximise productivity and fruit profits (Ruiz-Sanchez et al. 2010). Agricultural irrigation is inevitably associated with water quality deterioration through run-off to ground water, resulting in increased salts levels. A key factor when discussing supplementary irrigation is the electrical conductance (EC) of the water used. Citrus trees are sensitive to salinity stress, causing poor vegetative growth, reduced fruit yield and quality, and increased susceptibility to pathogens (Levy et al. 1999; Levy and Syvertsen 2004).

To alleviate problems with irrigation and salinity, citrus growers can use reclaimed water from packing-house washing and disinfection (Parsons et al. 2001), although this may encourage the spread of waterborne pathogens, such as $X$. citri. There are also alternative citrus rootstocks, such as Cleopatra mandarin (Citrus reshni Hort. ex Tan.) that are less susceptible to high soil salinity, but more 


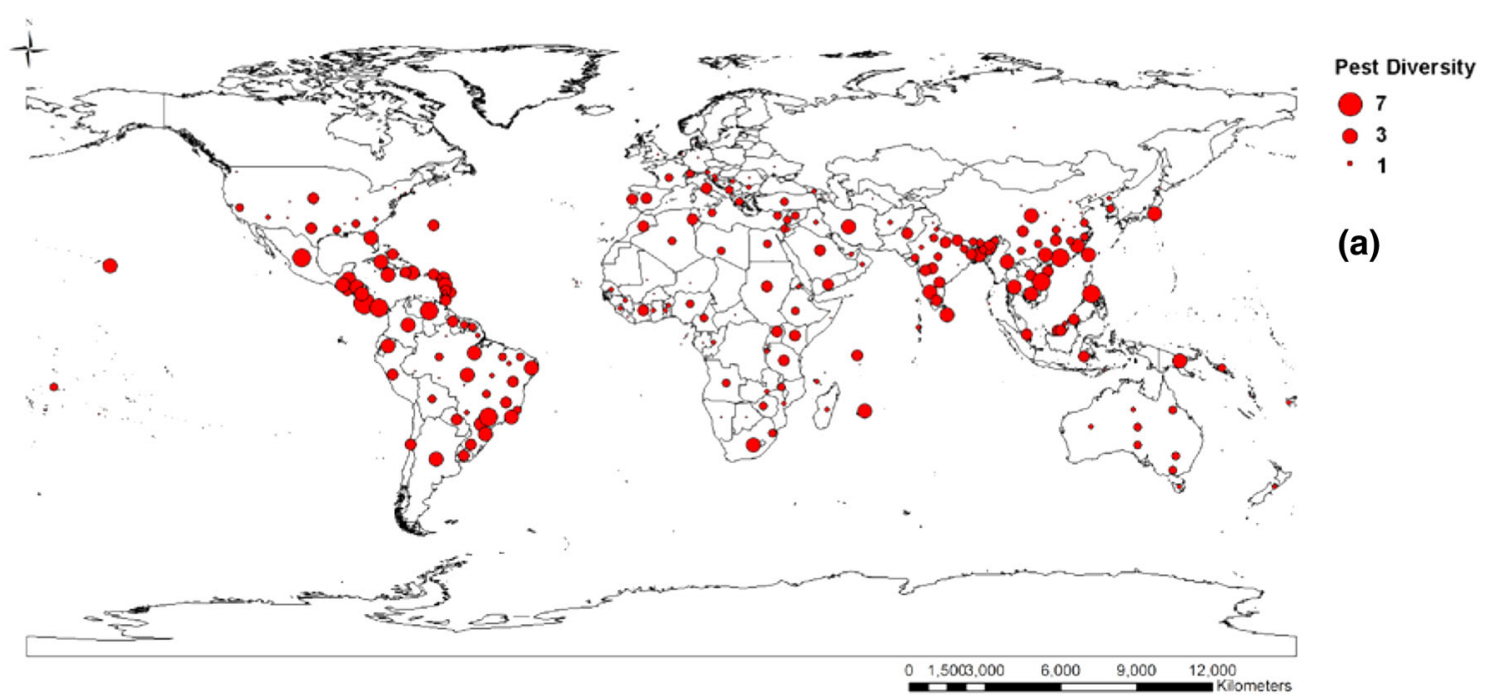

Before 1960

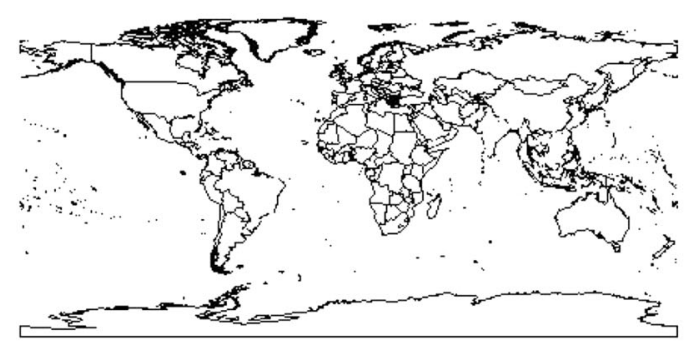

$1980-2000$

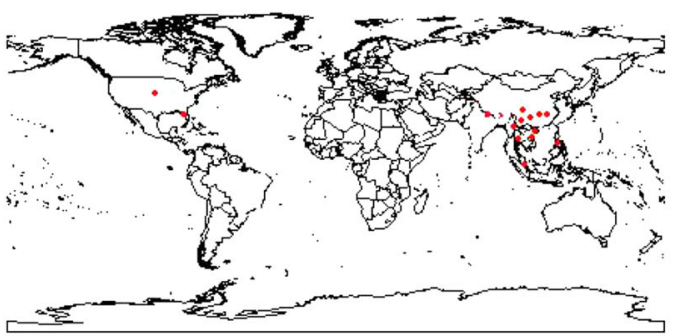

Fig. 2 Diversity of major invertebrate pests of lime that have detailed distribution data available (Asian citrus psyllid Diaphorina citri; Black citrus aphid Toxoptera citricida; Citrus leafhopper Hishimonus phycitis; Black and Citricola scale Saissetia oleae and Coccus pseudomagnoliarum; Citrus blackfly Aleurocanthus woglumi; Citrus

susceptible to Phytophthora pathogens (Forner et al. 2000; Moya et al. 2003).

Climatic models of future deterioration to water security and soil salinity levels (Vörösmarty et al. 2010) suggest that several key areas of citrus production may become unsustainable in the near future. Turkey, India and China are all key global producers of citrus that may have significant areas of water stress (Fig. 3a). Additionally, Iran,
$1960-1980$

(b)

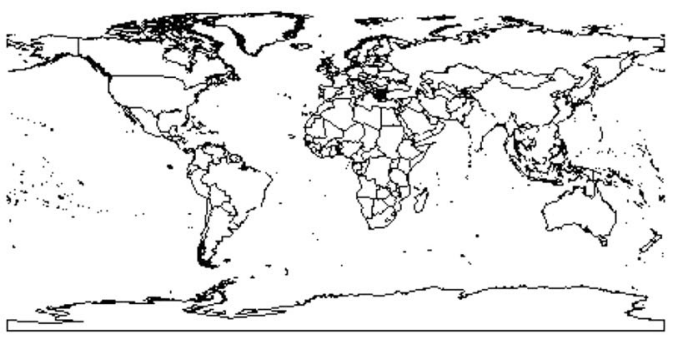

2000-Present

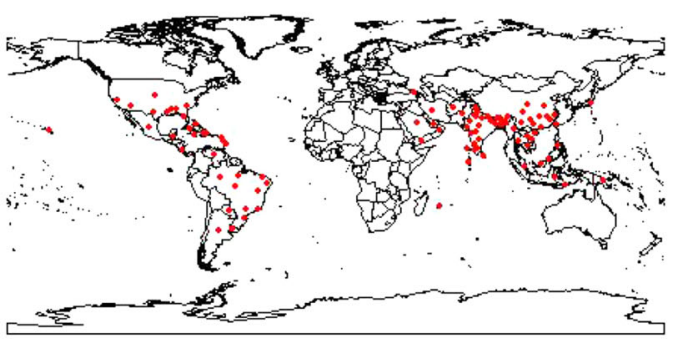

thrips Scirtothrips citri; Citrus longhorn beetle Anoplophora chinen$s i s$ ), for more detailed distributions of these pest species see supplementary materials (b) an example detailed distribution of $D$. citri from 1960 to 2016

Pakistan and India are also principal producers of lime that have their production threatened by increasing soil salinity (Fig. 3b). Susceptibility to water stress is linked to rootstock viability, and certain rootstocks that are less susceptible to water stress are threatened by Phytophthora (Moya et al. 2003).

Both resistance and tolerance to disease can be modulated not only by plant breeding, but also by nutrient 


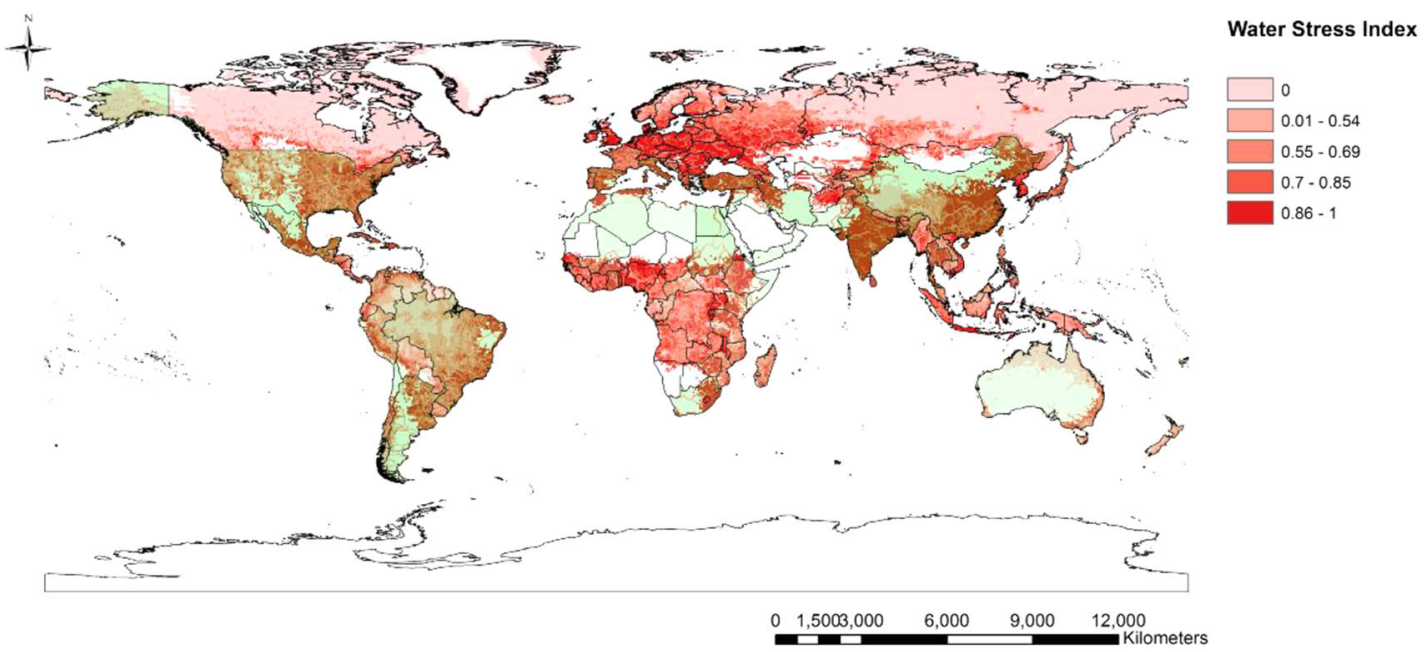

(a)

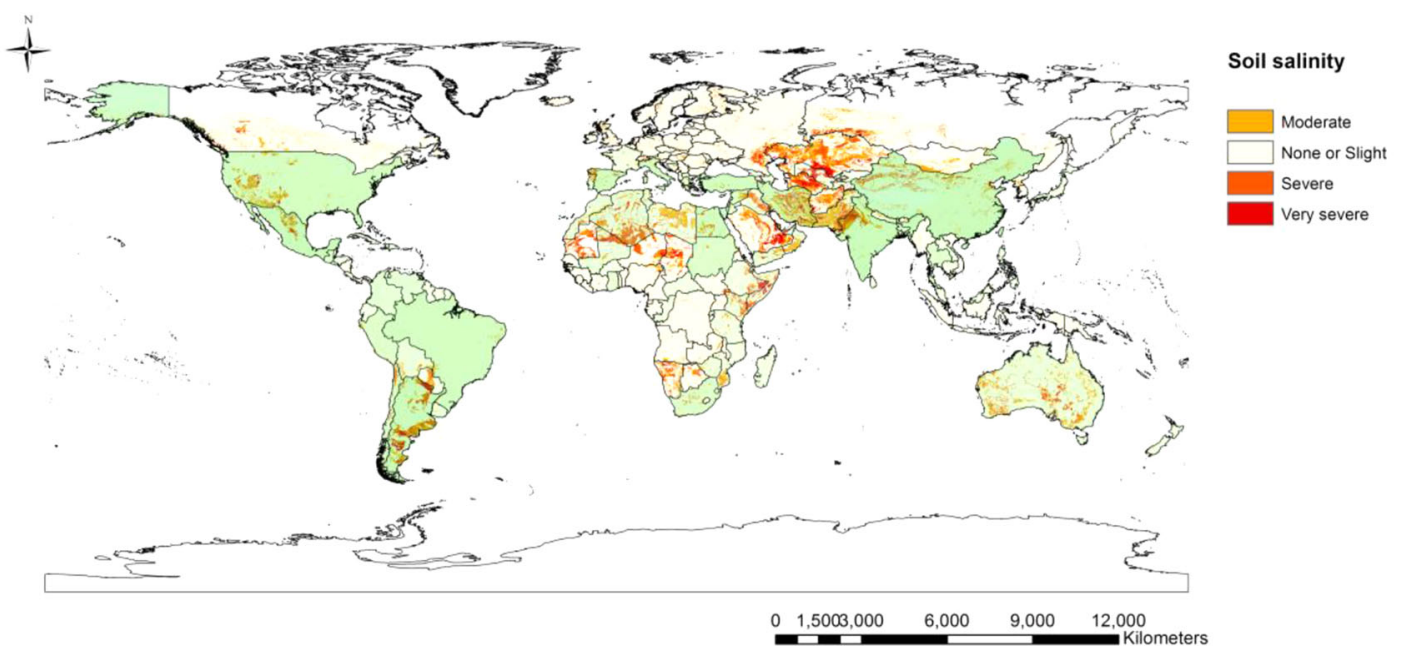

(b)

Fig. 3 a Global water stress in lime producing countries (highlighted in green) and b global soil excess salinity; indices derived from Vörösmarty et al. (2010)

availability (Huber et al. 2012). Over-application of fertilisers can have negative environmental impacts, through leaching of nutrients and pollution of local water courses. There may also be negative impacts to target plants; excess soil copper can lead to reduction in plant-available iron, resulting in chlorosis of citrus leaves (Stewart and Leonard 1952) and alteration of soil $\mathrm{pH}$. Excess copper applications often originate from excessive use of fungicidal sprays in citrus plantations (Fernandes and Henriques 1991), also highlighting the importance of appropriate applications of pest control products.

Recent advances in precision agriculture, whereby the inputs into a cropping system are calculated based on localscale variations in input requirements, may help address these deficiencies (Qamar uz and Schumann 2006; Jaramillo-Jaramillo 2016). Although it is limited by high equipment costs, precision agriculture like this can have significant benefits to crop production (Chandel et al. 2016).

\section{Climate change}

Increasing global temperatures as a result of climate change may influence the behaviour, distribution and breeding potential of citrus pests and pathogens. The complex trophic interactions in the plant-pathogen-vector triumvirate are difficult to fully understand (Richardson et al. 2000). For example, Candidatus Liberibacter asiaticus titers in citrus and acquisition rates by Diaphorina citri decline when plants are at warmer temperatures, which suggests that the incidence and spread of the pathogen are strongly influenced by ambient temperatures (Lopes et al. 2013).

Some modelling approaches suggest that spread of $D$. citri to new areas (such as southern coastal Australia) may 
result from climate change effects on timing and duration of new citrus growth, but these predictions are spatially dependent (Aurambout et al. 2009). Narouei-Khandan et al. (2016) have used two modelling approaches to predict global and local potential distribution of Huanglongbing (caused by $C a$. L. asiaticus) and its vector, D. citri. Globally, both models predicted that climates in large areas of Africa, Latin America and North Australia were highly suitable for $\mathrm{Ca}$. L. asiaticus and its vector, while the climate in the Mediterranean area was moderately suitable for $D$. citri but less suitable for $C a$. L. asiaticus, except for in southern Portugal and Spain.

Furthermore, shifts in phenology may also increase the risks posed by meteorological factors such as frost and storms (Fitchett et al. 2014). In a study on D. citri infected by an Isaria fumosorosea (i.e. an entomopathogenic fungus), Hussain et al. (2017) found that the insect metabolism was inhibited whilst longevity declined (e.g. from $500 \mathrm{~h}$ at $25{ }^{\circ} \mathrm{C}$ to $130 \mathrm{~h}$ at $41{ }^{\circ} \mathrm{C}$ ) with the increase in temperature; the same pattern was observed when insect were exposed to cooler temperatures. The study may have shed some light on how temperature will affect the pest biocontrol in a scenario of climate changes, whereas infestations by $B$. phoenicis seem to correlate positively to warmer temperatures and other climatic variables (e.g. longer days, lower relative humidity and lower evapotranspiration) (Laranjeira et al. 2015).

Citrus diseases may also be prone to climate changes. The rainfall distribution seem to have affected the natural spread of citrus black spot (CBS) disease, caused by Phyllosticta citricarpa, in South Africa over the last decades. Thus, the disease has expanded its original geographical range from summer rainfall to drier regions (Martínez-Minaya et al. 2015). The potential spread of the CBS disease had been CLIMEX modelled to predict the climatic suitability of Europe for harbouring Phyllosticta citricarpa. After being criticised by Authorities, a new CLIMEX model was developed and suggests that Europe, nearly in its all extension, is not appropriate for the disease; unlike South Africa and Australia where the disease is established (Yonow et al. 2013).

\section{Rootstock management}

Citrus nurseries are almost exclusively cultivated from rootstock shoot-tip-grafting. Troyer citrange is the most commonly used rootstock around the world for shoot-tipgrafting (STG), but due to the cosmopolitan nature of many lime pathogens, diversification in the use of resistant rootstocks beyond Troyer citrange may be necessary (Castle 2010). Many citrus rootstocks can have mycorrhizal associations: growth rates of Sour orange, Cleopatra mandarin and Rough lemon are dependent on mycorrhizae
(Menge et al. 1978). Troyer citrange, conversely, is capable of growth and establishment in the presence or absence of mycorrhizal fungi (Kleinschmidt and Gerdemann 1972). An exploratory breeding programme is being conducted to find novel citrus rootstocks for breeding programmes within the Mediterranean basin (Castle 2010; Snoussi-Trifa et al. 2015).

\section{Transport of infected germplasm}

Commercial citrus is mostly clonally propagated, therefore transmission of diseases through movement of infected germplasm may be an important pathway for quarantine pests and pathogens (Frison and Taher 1991; A. Al-Sadi, pers. obs.); asymptomatic pathogens that lie dormant in plant tissue, such as viruses, are of particular concern (Wilkes and Williams 1983). For example, the introduction of CTV to Argentina and Brazil via infected germplasm in 1920 's resulted in the loss of approximately 20 million highly susceptible trees (Krueger and Navarro 2007). Catastrophes such as these have resulted in restrictions on the transport of citrus materials and the establishment of quarantines and other regulations.

FAO and the International Board for Plant Genetic Resources have launched a collaborative programme for the safe movement of germplasm, focusing on registering sources of pathogen-free plant material and testing of the materials provided (Frison and Taher 1991).

\section{Trade and biosecurity}

International trade agreements have opened new market opportunities for citrus trading, for example the import market to USA has expanded following the North American Free Trade Agreement 1994 (Spreen 2000), allowing increased imports of lime from emerging citrus markets in Mexico and China. In contrast, citrus rootstock and germplasm trade into the European Union (EU) has been restricted by EU Council Directive 2000/29/EC, which prevents the movement of any plant material (other than fruits or seeds), derived of members of genus Citrus from being imported into the EU from any third party country. Although this allows the sale of marketable fruit to the EU, the directive limits the transmission of potentially infectious materials into the EU Economic Area.

\section{Weather crises}

Anomalous weather systems have caused significant damage to citrus production around the world; this was particularly apparent with the destruction of the lime industry in Florida following Hurricane Andrew in 1992 (Crane et al. 1996; DAC 2013). Future threats to lime production 
may also come from the long-term changes to the Pacific El Niño-La Niña weather cycle (Wang 1995). Post-harvest losses in lime are particularly sensitive to weather. For example in India, Pakistan and other South Asian countries, these losses are significantly greater in monsoon season, due to damage during transport and packing (Ladaniya 2015). Increasing instability in weather systems may therefore lead to increased post-harvest losses.

\section{Summary and conclusions}

Over the last 30 years, global lime production has been impacted by severe weather events and invasive insect pests and pathogens. The damage has been so severe as to make lime production in Florida, once one of the biggest producers in the world, now no longer financially viable (Evans et al. 2014). These crises have opened the possibility for new producers to invest in lime production; currently, the majority of the gap in the market left by Florida has been filled by Mexico (Spreen 2000). However, these emergent markets are also subject to the biotic and abiotic threats we have identified throughout this review.

Transmission of pathogens in agricultural systems occurs predominantly by transport of infected plant material or by insect vectors, which highlights two key focal pathways to production loss that must be addressed. Here, we have identified potential solutions that can be employed within the lime industry: creation, monitoring and testing of pathogen-free germplasm for new plantations, while integrated pest management strategies using biocontrol, adapted cultural practices, resistant varieties, biopesticides and chemical pesticides have shown some success in lime orchards globally.

Here, we have presented a systematic review of the global threats to agricultural production, and have connected the issues caused by pests and pathogens of with irrigation stresses, soil salinity (Vörösmarty et al. 2010) and improper cultural control practices. These abiotic factors may not only reduce the productivity of trees, but also increase the damage caused by pests and pathogens (Qamar uz and Schumann 2006; Huber et al. 2012). Although the focal point of this review has been citrus agricultural systems, the lessons regarding an integrated approach accounting for all biotic and abiotic factors may be applied to maximise production and quality with minimal inputs across all agricultural systems.

Acknowledgements The authors would like to thank Vale S.A. for financial support. SLE and CMC are in receipt of productivity grants from Conselho Nacional de Pesquisa (CNPq), Brazil.
Author contributions PD, AMA, CMC, SLE designed and coordinated the study and PD and SLE drafted the manuscript. All authors gave final approval for publication.

\section{Compliance with ethical standards}

Conflict of interest The authors declare that they have no conflict of interest.

Open Access This article is distributed under the terms of the Creative Commons Attribution 4.0 International License (http://creative commons.org/licenses/by/4.0/), which permits unrestricted use, distribution, and reproduction in any medium, provided you give appropriate credit to the original author(s) and the source, provide a link to the Creative Commons license, and indicate if changes were made.

\section{References}

Abad-Moyano R, Pina T, Perez-Panades J, Carbonell EA, Urbaneja A (2010) Efficacy of Neoseiulus californicus and Phytoseiulus persimilis in suppression of Tetranychus urticae in young clementine plants. Exp Appl Acarol 50:317-328

Achachi A, Ait Barka E, Ibriz M (2014) Recent advances in citrus psorosis virus. Virus Dis 25:261-276

Agunloye OJ (1987) Trapping and chemical control of Ceratitis capitata (Wied) (Diptera, Tephritidae) on sweet orange (Citrus sinensis) in Nigeria. J Hortic Sci 62:269-271

Ahlawatl Y, Gopal K, Charaya M (2005) Citrus yellow mosaic virus is associated with mosaic disease in Rangpur lime rootstock of citrus. Curr Sci 89:1596-1600

Akbari L, Seraj AA (2007) Predacious mites for control of citrus thrips, Scirtothrips citri (Thysanoptera: Thripidae) in nursery citrus. In: Proceedings of the XVI international plant protection congress, Glasgow, pp 312-313

Al Adawi A, Deadman M, Al Rawahi A, Al Maqbali Y, Al Jahwari A, Al Saadi B, Al Amri I, Wingfield M (2006) Aetiology and causal agents of mango sudden decline disease in the Sultanate of Oman. Eur J Plant Pathol 116:247-254

Al-Sadi A, Al-Moqbali H, Al-Yahyai R, Al-Said F (2012) AFLP data suggest a potential role for the low genetic diversity of acid lime (Citrus aurantifolia Swingle) in Oman in the outbreak of witches' broom disease of lime. Euphytica 188:285-297

Alva AK, Paramasivam S, Graham WD, Wheaton TA (2003) Best nitrogen and irrigation management practices for citrus production in sandy soils. Water Air Soil Pollut 143:139-154

Al-Yahyai RA, Al-Sadi AM, Al-Said FA, Al-Kalbani ZH, Carvalho CM, Elliot SL, Bertaccini A (2015) Development and morphological changes in leaves and branches of acid lime (Citrus aurantifolia) affected by witches' broom. Phytopathol Mediterr 54:133-139

Argov Y, Rossler Y (1996) Introduction, release and recovery of several exotic natural enemies for biological control of the citrus leaf miner, Phyllocnistis citrella, in Israel. Phytoparasitica 24:33-38

Arpaia ML, Morse JG (1991) Citrus thrips Scirtothrips citri (Moulton) (Thysanoptera: Thripidae) scarring and navel orange fruit quality in California. J Appl Entomol 111:28-32

Askari N, Nazari AH, Soheilivand S, Jouzani GS (2011) Evaluation of anti-phytoplasma properties of surfactin and tetracycline towards lime Witches Broom disease using real-time PCR. J Microbiol Biotechnol 21:81-88 
Aubert B (1987) Trioza erytreae Del Guercio and Diaphorina citri Kuwayama (Homoptera: Psylloidea), the two vectors of citrus greening disease: biological aspects and possible control strategies. Fruits 42:149-162

Aurambout JP, Finlay KJ, Luck J, Beattie GAC (2009) A concept model to estimate the potential distribution of the Asiatic citrus psyllid (Diaphorina citri Kuwayama) in Australia under climate change-a means for assessing biosecurity risk. Ecol Model 220:2512-2524

Bagheri A, Salehi M, Faghihi M, Samavi S, Sadeghi A (2009) Transmission of Candidatus Phytoplasma aurantifolia to Mexican lime by the leafhopper Hishimonus phycitis in Iran. J Plant Pathol 91:466

Baker AC (1944) A review of studies on the Mexican fruit fly and related Mexican species. Miscellaneous publication. United States Department of Agriculture, Washington, DC, p 176

Balock JW, Fernando LD (1969) Trapping for control of the Mexican fruit fly in mango and citrus groves. J Econ Entomol 62:53-56

Bar-Joseph M, Marcus R, Lee RF (1989) The continuous challenge of citrus tristeza virus control. Annu Rev Phytopathol 27:291-316

Bassanezi RB, Montesino LH, Stuchi ES (2009) Effects of huanglongbing on fruit quality of sweet orange cultivars in Brazil. Eur J Plant Pathol 125:565-572

Belay DK, Zewdu A, Foster JE (2011) Ecology and management of the woolly whitefly (Hemiptera: Aleyrodidae), a new invasive citrus pest in Ethiopia. J Econ Entomol 104:1329-1338

Ben-Dov Y (1993) A systematic catalogue of the soft scale insects of the world (Homoptera: Coccoidea: Coccidae) with data on geographical distribution, host plants, biology and economic importance. Sandhill Crane Press Inc, Gainesville, pp 14-28

Bergh JC (2001) Ecology and aerobiology of dispersing citrus rust mites (Acari: Eriophyidae) in central Florida. Environ Entomol 30:318-326

Berry RE (2003) Citrus fruits: Limes. In: Caballero B (ed) Encyclopedia of food sciences and nutrition. Academic Press, Oxford, pp 1368-1371

Bisen A, Pandey SK, Patel N (2012) Effect of skin coatings on prolonging shelf life of kagzi lime fruits (Citrus aurantiifolia Swingle). J Food Sci Technol 49:753-759

Bové JM (2006) Huanglongbing: a destructive, newly-emerging, century-old disease of citrus. J Plant Pathol 88:7-37

Bové J, Ayres AJ (2007) Etiology of three recent diseases of citrus in Sao Paulo State: sudden death, variegated chlorosis and huanglongbing. IUBMB Life 59:346-354

Bové JM, Garnier M (2000) Witches' broom disease of lime. Arab J Plant Prot 18:148-152

Bové J, Danet J, Bananej K, Hassanzadeh N, Taghizadeh M, Salehi M, Garnier M (2000) Witches' broom disease of lime (WBDL) in Iran. In; Proceedings of 14th conference IOCV, IOCV, Riverside, pp 207-212

Boykin LM, Shatters RG Jr, Hall DG, Burns RE, Franqui RA (2006) Analysis of host preference and geographical distribution of Anastrepha suspensa (Diptera: Tephritidae) using phylogenetic analyses of mitochondrial cytochrome oxidase I DNA sequence data. Bull Entomol Res 96:457-469

CABI (2015) Invasive species compendium. http://www.cabi.org/isc/. Accessed 21 June 2016

Carrillo D, Frank JH, Rodrigues JCV, Peña JE (2012) A review of the natural enemies of the red palm mite, Raoiella indica (Acari: Tenuipalpidae). Exp Appl Acarol 57:347-360

Carvalho SA, Santos FA, Machado MA (2002) Psorosis virus complex elimination from citrus by shoot-tip-grafting associated to thermotherapy. Fitopatol Bras 27:306-308

Castle WS (2010) A career perspective on citrus rootstocks, their development, and commercialization. HortScience 45:11-15
Chagas M, Parra JR, Namekata T, Hartung JS, Yamamoto PT (2001) Phyllocnistis citrella Stainton (Lepidoptera: Gracillariidae) and its relationship with the citrus canker bacterium Xanthomonas axonopodis pv citri in Brazil. Neotrop Entomol 30:55-59

Chandel N, Mehta C, Tewari V, Nare B (2016) Digital map-based site-specific granular fertilizer application system. Curr Sci 111:1208-1213

Chen J, Pu X, Deng X, Liu S, Li H, Civerolo E (2009) A phytoplasma related to 'Candidatus Phytoplasma asteris' detected in citrus showing huanglongbing (Yellow Shoot Disease) symptoms in Guangdong, PR China. Phytopathology 99:236-242

Chien C-C, Chiu S-C, Ku S (1989) Biological control of Diaphorina citri in Taiwan. Fruits 44:401-407

Childers CC (1994) Feeding injury to Robinson tangerine leaves by Brevipalpus mites (Acari, Tenuipalpidae) in Florida and evaluation of chemical control on Citrus. Fla Entomol 77:265-271

Chisholm MG, Wilson MA, Gaskey GM (2003) Characterization of aroma volatiles in key lime essential oils (Citrus aurantifolia Swingle). Flavour Fragr J 18:106-115

Chung K-R, Khan I, Brlansky R (2009) Citrus diseases exotic to Florida: Witches' Broom disease of lime (WBDL). Fact Sheet PP-228 Institute of Food and Agricultural Sciences, University of Florida

Colombo M, Limonta L (2001) Anoplophora malasiaca Thomson (Coleoptera Cerambycidae Lamiinae Lamiini) in Europe. Boll Zool Agrar Bachic 33:65-68

Coy MR, Hoffmann M, Kingdom Gibbard HN, Kuhns EH, PelzStelinski KS, Stelinski LL (2014) Nested-quantitative PCR approach with improved sensitivity for the detection of low titer levels of Candidatus Liberibacter asiaticus in the Asian citrus psyllid, Diaphorina citri Kuwayama. J Microbiol Methods 102:15-22

Crane JH, Campbell RJ, Balerdi CF (1993) Effect of hurricane Andrew on tropical fruit trees. In: Proceedings of Florida state horticultural society. Florida State Horticultural Society, pp 139-139

da Graça JV (2004) Etiology, history and world situation of citrus Huanglongbing. In: $S$ Naqvi (ed) Diseases of fruits and vegetables: diagnosis and management, vol 1. Kluwer Academic Publishers, Dordrecht

da Graça JV, Maharaj S (1991) Citrus vein enation virus, a probable luteovirus. In: Proceedings of the 11th conference of the international organization of citrus Virologists, Riverside, California, USA, pp 391-394

DAC (2013) Model profile of 1.0 ha citrus cultivation. Department of Agriculture, Cooperation and Farmers Welfare. Ministry of Agriculture and Farmers Welfare, Government of India. https:// www.nabard.org/pdf/Citrus_cultivation.pdf. Accessed on 07 Sept 15

Dahiya K, Lakra R, Dahiya A, Singh S (1994) Bioefficacy of some insecticides against citrus psylla, Diaphorina citri Kuw. (Psyllidae: Homoptera). Crop Res 8:137-140

de Carvalho SA, de Carvalho Nunes WM, Belasque J Jr, Machado MA, Croce-Filho J, Bock CH, Abdo Z (2015) Comparison of resistance to asiatic citrus canker among different genotypes of citrus in a long-term canker-resistance field screening experiment in Brazil. Plant Dis 99:207-218

Deng S, Hiruki C (1991) Genetic relatedness between two nonculturable mycoplasmalike organisms revealed by nucleic acid hybridization and polymerase chain reaction. Phytopathology 81:1475-1479

Domínguez A, Guerri J, Cambra M, Navarro L, Moreno P, Pen L (2000) Efficient production of transgenic citrus plants expressing the coat protein gene of citrus tristeza virus. Plant Cell Rep 19:427-433 
Duke JA, duCellier JL (1993) CRC handbook of alternative cash crops. CRC Press, Florida, pp 139-145

Economos C, Clay WD (1999) Nutritional and health benefits of citrus fruits. Food Nutr Agric 24:11-18

EPPO (2015) PQR - EPPO plant quarantine data retrieval system. http://www.eppo.int/DATABASES/pqr/pqr.htm. Accessed 21 June 2016

Epsky ND, Hendrichs J, Katsoyannos BI, Vásquez LA, Ros JP, Zümreoglu A, Pereira R, Bakri A, Seewooruthun SI, Heath RR (1999) Field evaluation of female-targeted trapping systems for Ceratitis capitata (Diptera: Tephritidae) in seven countries. J Econ Entomol 92:156-164

Eskafi FM (1988) Infestation of Citrus by Anastrepha spp. and Ceratitis capitata (Diptera: Tephritidae) in High Coastal Plains of Guatemala. Environ Entomol 17:52-58

Evans EA, Ballen FH, Crane JH (2014) Economic potential of producing Tahiti limes in Southern Florida in the presence of citrus canker and citrus greening. HortTechnology 24:99-106

Fadamiro HY, Akotsen-Mensah C, Xiao Y, Anikwe J (2013) Field evaluation of predacious mites (Acari: Phytoseiidae) for biological control of citrus red mite, Panonychus citri (Trombidiformes: Tetranychidae). Fla Entomol 96:80-91

FAO (2015) FAOSTAT: food and agriculture organization of the United Nations Statistics division. http://faostat3.fao.org. Accessed 21 June 2016

Fernandes J, Henriques F (1991) Biochemical, physiological, and structural effects of excess copper in plants. Bot Rev 57:246-273

Fitchett JM, Grab SW, Thompson DI, Roshan G (2014) Increasing frost risk associated with advanced citrus flowering dates in Kerman and Shiraz, Iran: 1960-2010. Int J Biometeorol 58:1811-1815

Flechtmann CH (1999) Tegolophus brunneus n. sp., a new citrus rust mite from Brazil (Acari: Eriophyidae). Int J Acarol 25:265-267

Forner J, Forner M, Alcaide A, Verdejo-Lucas S, Sorribas F (2000) New hybrid citrus rootstocks released in Spain. Proc Int Soc Citric I:58-61

Garnsey S, Gottwald T, Yokomi R (1996) Control strategies for citrus tristeza virus. In: Hadidi A, Khetarpal R, Koganezawa H (eds) Plant viral disease control: principles and practices. APS Press, St. Paul

Gasparoto MCG, Coletta-Filho HD, Bassanezi RB, Lopes SA, Lourenço SA, Amorim L (2012) Influence of temperature on infection and establishment of 'Candidatus Liberibacter americanus' and 'Candidatus Liberibacter asiaticus' in citrus plants. Plant Pathol 61:658-664

Ghai S, Shenhmar M (1984) A review of the world fauna of Tenuipalpidae (Acarina: Tetranychoidea). Orient Insects 18:99-172

Ghosh D, Das A, Singh S, Singh S, Ahlawat Y (1999) Occurrence of Witches'-Broom, a new phytoplasma disease of acid lime (Citrus aurantifolia) in India. Plant Dis 83:302

Ghosh D, Bhose S, Manimekalai R, Gowda S (2013) Molecular detection of Candidatus Phytoplasma spp. causing witches' broom disease of acid lime (Citrus aurantifolia) in India. J Plant Biochem Biotechnol 22:343-347

Giliomee J, Millar I (2009) The woolly whitefly, Aleurothrixus floccosus (Maskell)(Hemiptera: Aleyrodidae), a potentially serious citrus pest, recorded from South Africa. Afr Entomol $17: 232-233$

Gimenes-Fernandes N, Bassanezi RB (2001) Doença de causa desconhecida afeta pomares cítricos no norte de São Paulo e sul do Triângulo Mineiro. Summa Phytopathol 27:93

Gonçalves-Zuliani AM, Nanami DS, Barbieri BR, Guedes TA, Zanutto CA, Bock CH, Nunes WM (2016) Evaluation of resistance to asiatic citrus canker among selections of Pêra sweet orange (Citrus sinensis). Plant Dis 100:1994-2000
Gottwald TR, da Graça JV, Bassanezi RB (2007) Citrus huanglongbing: the pathogen and its impact. Plant Health Prog 6:1-18

Grafton-Cardwell EE, Ouyang Y, Striggow RA (1999) Predacious mites for control of citrus thrips, Scirtothrips citri (Thysanoptera: Thripidae) in nursery citrus. Biol Control 14:29-36

Grafton-Cardwell EE, Lee JE, Stewart JR, Olsen KD (2006) Role of two insect growth regulators in integrated pest management of citrus scales. J Econ Entomol 99:733-744

Grafton-Cardwell EE, Stelinski LL, Stansly PA (2013) Biology and management of Asian Citrus Psyllid, vector of the Huanglongbing pathogens. Annu Rev Entomol 58:413-432

Graham JH, Duncan LW, Eissenstat DM (1997) Carbohydrate allocation patterns in citrus genotypes as affected by phosphorus nutrition, mycorrhizal colonization and mycorrhizal dependency. New Phytol 135:335-343

Guanilo AD, Martínez N (2007) Predadores asociados a Panonychus citri McGregor (Acari: Tetranychidae) en la costa central del Perú. Ecol Apl 6:119-129

Halbert SE, Manjunath KL (2004) Asian citrus psyllids (Sternorrhyncha: Psyllidae) and greening disease of citrus: a literature review and assessment of risk in Florida. Fla Entomol $87: 330-353$

Halbert SE, Núñez CA (2004) Distribution of the Asian Citrus Psyllid, Diaphorina Citri Kuwayama (Rhynchota: Psyllidae) in the Caribbean Basin. Fla Entomol 87:401-402

Heath M, Kuhn D, Schnell R, Olano C (2002) Mitochondrial DNA restriction map for the Caribbean fruit fly, Anastrepha suspensa, and occurrence of mitochondrial DNA diversity within highly inbred colonies. Biochem Genet 40:283-292

Hendrichs J, Katsoyannos BI, Wornoayporn V, Hendrichs MA (1994) Odour-mediated foraging by yellowjacket wasps (Hymenoptera: Vespidae): predation on leks of pheromone-calling Mediterranean fruit fly males (Diptera: Tephritidae). Oecologia 99:88-94

Heppner JB (1993) Citrus Leafminer Phyllocnistis citrella in Florida (Lepidoptera: Gracillariidae: Phyllocnistinae). Trop Lepid $1: 49-64$

Hu J, Angeli S, Schuetz S, Luo Y, Hajek AE (2009) Ecology and management of exotic and endemic Asian longhorned beetle Anoplophora glabripennis. Agric For Entomol 11:359-375

Huber D, Römheld V, Weinmann M (2012) Chapter 10-relationship between nutrition, plant diseases and pests. In: Marschner P (ed) Marschner's mineral nutrition of higher plants, 3rd edn. Academic Press, San Diego, pp 283-298

Hussain M, Senyo Akutse K, Ravindran K, Lin Y, Steve Bamisile B, Qasim M, Wang L (2017) Effects of different temperature regimes on survival of diaphorina citri and its endosymbiotic bacterial communities. Environ Microbiol. https://doi.org/10. $1111 / 1462-2920.13821$

Hyun JW, Timmer LW, Lee SC, Yun SH, Ko SW, Kim KS (2001) Pathological characterization and molecular analysis of elsinoe isolates causing scab diseases of citrus in Jeju Island in Korea. Plant Dis 85:1013-1017

Irshad U, Mukhtar T, Ashfaq M, Kayani M, Kayani S, Hanif M, Aslam S (2012) Pathogenicity of citrus nematode (Tylenchulus semipenetrans) on Citrus jambhiri. J Anim Plant Sci 22:1014-1018

Jaramillo-Jaramillo DF (2016) Definition of homogeneous fertility areas through factorial and geostatistical analysis. Boletín de Ciencias de la Tierra 1:5-11

Kanmiya K, Sonobe R (2002) Records of two citrus pest whiteflies in Japan with special reference to their mating sounds (Homoptera: Aleyrodidae). Appl Entomol Zool 37:487-495

Kaplan DT (1981) Characterization of citrus rootstock responses to Tylenchulus semipenetrans (Cobb). J Nematol 13:492 
Kashio T, Ujiye T (1988) Evaluation of the use of the entomogenous fungus, Beauveria tenella, isolated from the yellow spotted longicorn beetle, Psacothea hilaris for the biological control of the white spotted longicorn beetle Anoplophora malasiaca. In: Proceedings of the association for plant protection of Kyushu, pp 190-193

Katsoyannos P, Ifantis K, Kontodimas D (1997) Phenology, population trend and natural enemies of Aleurothrixus floccosus (Hom.: Aleyrodidae) at a newly invaded area in Athens, Greece. Entomophaga 42:619-628

Kleinschmidt G, Gerdemann J (1972) Stunting of citrus seedlings in fumigated nursery soils related to the absence of endomycorrhizae. Phytopathology 62:1447-1453

Kotzé J (1981) Epidemiology and control of citrus black spot in South Africa. Plant Dis 65:945-950

Krueger RR, Navarro L (2007) Four citrus germplasm resources. In: Khan I (ed) Citrus genetics, breeding and biotechnology. CABI Press, Wallingford, $\mathrm{p} 45$

Kumar V, Kumar M, Singh J, Baranwal VK (2015) Molecular detection and characterization of citrus yellow mosaic virus associated with acid lime (Citrus aurantifolia). J Pure Appl Microbiol 9:1025-1032

Ladaniya (2015) Postharvest management of citrus fruit in south Asian countries. In: SabaterMunoz B, Moreno P, Pena L, Navarro L (eds) Xii international citrus congress-international society of citriculture, vol 1. International Society of Horticultural Science, Leuven, pp 1669-1676

Laranjeira FF, de Brito Silva SX, de Andrade EC, de Oliveira Almeida D, da Silva TSM, Soares ACF, Freitas-Astúa J (2015) Infestation dynamics of Brevipalpus phoenicis (Geijskes)(Acari: Tenuipalpidae) in citrus orchards as affected by edaphic and climatic variables. Exp Appl Acarol 66:491-508

Le Roux H, Van Vuuren S, Pretorius M, Buitendag C (2006) Management of huanglongbing in South Africa. In: Proceedings of the Huanglongbing-Greening Intl. Workshop, Ribeirão, Brazil, pp 43-47

Lee I-M, Hammond R, Davis R, Gundersen D (1993) Universal amplification and analysis of pathogen $16 \mathrm{~S}$ rDNA for classification and identification of mycoplasmalike organisms. Phytopathology 83:834-842

Legaspi JC, French JV, Schauff ME, Woolley JB (1999) The citrus leafminer Phyllocnistis citrella (Lepidoptera: Gracillariidae) in South Texas: incidence and parasitism. Fla Entomol 82:305-316

Levy Y, Syvertsen J (2004) Irrigation water quality and salinity effects in citrus trees. Hortic Rev 30:37-82

Levy Y, Lifshitz J, De Malach Y, David Y (1999) The response of several Citrus genotypes to high-salinity irrigation water. HortScience 34:878-881

Liu YH, Tsai JH (2000) Effects of temperature on biology and life table parameters of the Asian citrus psyllid, Diaphorina citri Kuwayama (Homoptera: Psyllidae). Ann Appl Biol 137:201-206

Liu Y, Heying E, Tanumihardjo SA (2012) History, global distribution, and nutritional importance of citrus fruits. Compr Rev Food Sci Food Saf 11:530-545

Locali EC, Freitas-Astua J, de Souza AA, Takita MA, Astua-Monge G, Antonioli R, Kitajima EW, Machado MA (2003) Development of a molecular tool for the diagnosis of leprosis, a major threat to citrus production in the Americas. Plant Dis 87:1317-1321

Lopes SA et al (2013) 'Candidatus Liberibacter asiaticus' titers in citrus and acquisition rates by Diaphorina citri are decreased by higher temperature. Plant Dis 97(12):1563-1570

Lota M-L, de Rocca Serra D, Tomi F, Jacquemond C, Casanova J (2002) Volatile components of peel and leaf oils of lemon and lime species. J Agric Food Chem 50:796-805
Lotto GD (1976) On the black scales of southern Europe (Homoptera: Coccoidea: Coccidae). J Entomol Soc South Afr 39:147-149

Mabberley D (2004) Citrus (Rutaceae): a review of recent advances in etymology, systematics and medical applications. Blumea Biodivers Evol Biogeogr Plants 49:481-498

Maccheroni W, Alegria MC, Greggio CC, Piazza JP, Kamla RF, Zacharias PRA, Bar-Joseph M, Kitajima EW, Assumpção LC, Camarotte G, Cardozo J, Casagrande EC, Ferrari F, Franco SF, Giachetto PF, Girasol A, Jordão H, Silva VHA, Souza LCA, Aguilar-Vildoso CI, Zanca AS, Arruda P, Kitajima JP, Reinach FC, Ferro JA, da Silva ACR (2005) Identification and genomic characterization of a new virus (Tymoviridae Family) associated with citrus sudden death disease. J Virol 79:3028-3037

Manrakhan A, Stephen PR, Cronje PJR (2015) Phytotoxic effect of GF-120 NF fruit fly bait on fruit of mandarin (Citrus reticulata Blanco cv. Nadorcott): influence of bait characteristics and fruit maturity stage. Crop Prot 78:48-53

Mardi M, Khayam Nekouei S, Farsad LK, Ehya F, Shabani M, Shafiee M, Tabatabaei M, Safarnejad MR, Salehi Jouzani G, Hosseini Salekdeh G (2011) Witches' broom disease of Mexican lime trees: disaster to be addressed before it will be too late. Bull Insectol 64:S205-S206

Martín S, Alioto D, Milne RG, Guerri J, Moreno P (2002) Detection of citrus psorosis virus in field trees by direct tissue blot immunoassay in comparison with ELISA, symptomatology, biological indexing and cross-protection tests. Plant Pathol $51: 134-141$

Martínez-Minaya J, Conesa D, López-Quílez A, Vicent A (2015) Climatic distribution of citrus black spot caused by Phyllosticta citricarpa. A historical analysis of disease spread in South Africa. Eur J Plant Pathol 143:69-83

Matheron ME, Porchas M, Matejka J (1997) Distribution and seasonal population dynamics of Phytophthora citrophthora and $P$. parasitica in Arizona citrus orchards and effect of fungicides on tree health. Plant Dis 81:1384-1390

McCoy CW, Albrigo LG (1975) Feeding injury to the orange caused by the Citrus rust mite, Phyllocoptruta oleivora (Prostigmata: Eriophyoidea). Ann Entomol Soc Am 68:289-297

McCoy CW, Samson RA, Boucias DG, Osborne LS, Pena JE, Buss LJ (2009) Pathogens infecting insects and mites of Citrus. LLC Friends of Microbes, Winter Park

McCready RM, Walter ED, Maclay WD (1950) Sugars of citrus juices. Food Technol 4:19-20

Mendel K (1969) The influence of temperature and light on the vegetative development of citrus trees. In: Proceedings international citrus symposium. University of California, Riverside, pp 259-265

Menge JA, Johnson ELV, Platt RG (1978) Mycorrhizal dependency of several citrus cultivars under three nutrient regimes. New Phytol 81:553-559

Mercado VT, Fernández ES, Giliomee JH (2014) Life table parameters of the woolly whitefly Aleurothrixus floccosus (Hemiptera: Aleyrodidae) and its parasitoid Cales noacki (Hymenoptera: Aphelinidae). Eur J Entomol 111:251

Miklasiewicz T, Walker G (1990) Population dynamics and biological control of the woolly whitefly (Homoptera: Aleyrodidae) on citrus. Environ Entomol 19:1485-1490

Moreno P, Ambrós S, Albiach-Martí MR, Guerri J, Pena L (2008) Citrus tristeza virus: a pathogen that changed the course of the citrus industry. Mol Plant Pathol 9:251-268

Morse JG, Brawner OL (1986) Toxicity of pesticides to Scirtothrips citri (Thysanoptera: Thripidae) and implications to resistance management. J Econ Entomol 79:565-570

Morton J (1987) Mexican lime. In: Fruits of warm climates. Julia F. Morton, Miami, FL, pp 168-172 
Moya JL, Gómez-Cadenas A, Primo-Millo E, Talon M (2003) Chloride absorption in salt-sensitive Carrizo citrange and salttolerant Cleopatra mandarin citrus rootstocks is linked to water use. J Exp Bot 54:825-833

Mukhopadhyay S (2004) Diseases of citrus and their management. Citrus: production, postharvest, disease and pest management. Science Publishers, Enfield, pp 90-196

Munankarmi N, Shrestha R, Rana N, Shrestha J, Shrestha S, Koirala $\mathrm{R}$ (2014) Genetic diversity assessment of acid lime (Citrus aurantifolia Swingle) landraces of Eastern Nepal using RAPD markers. Int J Appl Sci Biotechnol 2:315-327

Murai M (1974) Studies on the interference among larvae of the citrus leaf miner, Phyllocnistis citrella stainton (Lepidoptera: Phyllocnistidae). Res Popul Ecol 16:80-111

Narang N, Jiraungkoorskul W (2016) Anticancer activity of key lime, Citrus aurantifolia. Pharmacogn Rev 10:118-122

Nascimento da Silva F, Neves de Souza A, Al-Mahmooli I, Al-Sa'di AM, Carvalho CM (2015) A new disease in Citrus aurantifolia in Oman, "sudden decline", is associated with a pathogen complex including a 16SrII group phytoplasma. Phytopathogenic Mollicutes 5(1s):S101-S102

Navarro L (1993) Citrus sanitation, quarantine and certification programs. In: Proceedings of the 12th conference of the international organization of citrus virologists. International Organization of Citrus Virologists, Riverside, pp 383-391

Navia D, Ochoa R, Welbourn C, Ferragut F (2009) Adventive eriophyoid mites: a global review of their impact, pathways, prevention and challenges. Eriophyoid Mites: Progress and Prognoses. Springer, Berlin, pp 225-255

Nemec S (1978) Symptomatology and histopathology of fibrous roots of rough lemon (Citrus limon) infected with Fusarium solani. Mycopathologia 63:35-40

Obenland DM, Jang EB, Aung LH, Zettler L (1998) Tolerance of lemons and the Mediterranean fruit fly to carbonyl sulfide quarantine fumigation. Crop Prot 17:219-224

Omoto C, Dennehy TJ, McCoy CW, Crane SE, Long JW (1994) Detection and characterization of the interpopulation variation of citrus rust mite (Acari: Eriophyidae) resistance to dicofol in Florida citrus. J Econ Entomol 87:566-572

Parsons LR, Wheaton TA, Castle WS (2001) High application rates of reclaimed water benefit citrus tree growth and fruit production. HortScience 36:1273-1277

Plattner K (2014) Fresh-market limes. In: USDA (ed) Fruit and tree nuts outlook: economic insigh. FTS-357SA, Washington, DC

Qamar uz Z, Schumann AW (2006) Nutrient management zones for citrus based on variation in soil properties and tree performance. Precis Agric 7:45-63

Queiroz RB, Donkersley P, Silva FN, Al-Mahmmoli IH, Al-Sadi AM, Carvalho CM, Elliot SL (2016) Invasive mutualisms between a plant pathogen and insect vectors in the Middle East and Brazil. R Soc Open Sci 3:160557

Richardson DM, Allsopp N, D'Antonio CM, Milton SJ, Rejmanek M (2000) Plant invasions-the role of mutualisms. Biol Rev 75:65-93

Rodrigues JCV, Kitajima EW, Childers CC, Chagas CM (2003) Citrus leprosis virus vectored by Brevipalpus phoenicis (Acari: Tenuipalpidae) on citrus in Brazil. Exp Appl Acarol 30:161-179

Rodríguez G, Garza L, Stapleton J, Civerolo E (1985) Citrus bacteriosis in Mexico. Plant Dis 69:808-810

Roistacher CN (1991) Graft-transmissible diseases of citrus: handbook for detection and diagnosis. Food and Agriculture Organization, Rome

Ruiz-Arce R, Owen CL, Thomas DB, Barr NB, McPheron BA (2015) Phylogeographic structure in Anastrepha ludens (Diptera: Tephritidae) populations inferred with mtDNA sequencing. J Econ Entomol 108:1324-1336
Ruiz-Sanchez MC, Domingo R, Castel JR (2010) Review. Deficit irrigation in fruit trees and vines in Spain. Span J Agric Res 8:S5-S20

Sabelis MW (1996) Phytoseiidae. In: Lindquist EE, Sabelis MW, Bruin J (eds) Eriophyoid mites: their biology, natural enemies and control. Elsevier, Amsterdam, pp 427-456

Salehi M, Izadpanah K, Siampour M, Bagheri A, Faghihi S (2007) Transmission of 'Candidatus Phytoplasma aurantifolia' to Bakraee (Citrus reticulata hybrid) by feral Hishimonus phycitis leafhoppers in Iran. Plant Dis 91:466

Sambade A, Rubio L, Garnsey SM, Costa N, Müller GW, Peyrou M, Guerri J, Moreno P (2002) Comparison of viral RNA populations of pathogenically distinct isolates of Citrus tristeza virus: application to monitoring cross-protection. Plant Pathol $51: 257-265$

Samson J (1986) Citrus. Longman Scientific and Technical, Essex

Saunt J (1990) Citrus varieties of the world. An illustrated guide, Sinclair International Ltd, Norwich

Schauff ME, LaSalle J, Wijesekara GA (1998) The genera of chalcid parasitoids (Hymenoptera : Chalcidoidea) of citrus leafminer Phyllocnistis citrella Stainton (Lepidoptera : Gracillariidae). J Nat Hist 32:1001-1056

Scott RR, Shen J, Bugang W, Riedel M (2012) Citrus annual. Global Agricultural Information Network, FAS Office of Agricultural Affairs, Beijing

Silva F, Queiroz R, Souza A, Al-Sadi A, Siqueira D, Elliot S, Carvalho C (2014) First report of a 16SrII-C phytoplasma associated with asymptomatic acid lime (Citrus aurantifolia) in Brazil. Plant Dis 98:1577

Snoussi-Trifa H, Duval MF, Garcia-Lor A, Perrier X, JacquemoudCollet JP, Navarro L, Ollitrault P (2015) Analysis of genetic diversity in Tunisian citrus rootstocks. In: SabaterMunoz B, Moreno P, Pena L, Navarro L (eds) Xii international citrus congress-international society of citriculture, vol 1. International Society of Horticultural Science, Leuven, p 147

Sohi A, Bindra O, Deol G (1974) Studies on the control of the brinjal little-leaf disease and insect pests of brinjal. Indian J Entomol 36:362-364

Soto A, Ohlenschläeger F, García-marí F (2002) Distribution and sampling of the whiteflies Aleurothrixus floccosus, Dialeurodes citri, and Parabemisia myricae (Homoptera: Aleyrodidae) in Citrus in Spain. J Econ Entomol 95:167-173

Spreen TH (2000) The citrus industries of the United States and Mexico after NAFTA. Rev Chapingo Ser Hortic 6:145-152

Stewart I, Leonard C (1952) Chelates as sources of iron for plants growing in the field. Science 116:564-566

Swingle WT, Reece PC (1967) The botany of citrus and its wild relatives. In: Reuther W, Webber HJ, Batchelor ED (eds) The citrus industry. University of California Press, Berkeley, pp 190-430

Tena A, Garcia-Marí F (2008) Suitability of citricola scale Coccus pseudomagnoliarum (Hemiptera: Coccidae) as host of Metaphycus helvolus (Hymenoptera: Encyrtidae): Influence of host size and encapsulation. Biol Control 46:341-347

Texeira DC, Ayres J, Kitajima EW, Danet L, Jagoueix-Eveillard S, Saillard C, Bové JM (2005) First report of a Huanglongbing-like disease of citrus in Sao Paulo state, Brazil and association of a new liberibacter species, "Candidatus Liberibacter americanus", with the disease. Plant Dis 89:107

Timmer L, Menge J, Zitko S, Pond E, Miller S, Johnson E (1993) Comparison of ELISA techniques and standard isolation methods for Phytophthora detection in citrus orchards in Florida and California. Plant Dis 77:791-796

Timmer LW, Garnsey SM, Graham JH (2000) Compendium of citrus diseases. APS Press, St. Paul 
Tucker DPH, Alva A, Jackson L, Wheaton T (1995) Nutrition of Florida citrus trees. Cooperative Extension Service, University of Florida, Institute of Food and Agricultural Sciences, Gainesville

Uchoa-Fernandes MA, de Oliveira I, Molina RMS, Zucchi RA (2003) Biodiversity of frugivorous flies (Diptera: Tephritoidea) captured in citrus groves, Mato Grosso do Sul, Brazil. Neotrop Entomol 32:239-246

Umeh VC, Adeyemi A (2011) Population dynamics of the woolly whitefly Aleurothrixus floccosus (Maskell) on sweet orange varieties in Nigeria and association of A. floccosus with the entomopathogenic fungi Aschersonia spp. Fruits 66:385-392

Vacante V (2010) Citrus mites: identification, bionomy and control. CABI, Preston

Van Leeuwen T, Tirry L, Yamamoto A, Nauen R, Dermauw W (2015) The economic importance of acaricides in the control of phytophagous mites and an update on recent acaricide mode of action research. Pestic Biochem Physiol 121:12-21

Vargas RI, Peck SL, McQuate GT, Jackson CG, Stark JD, Armstrong JW (2001) Potential for areawide integrated management of Mediterranean fruit fly (Diptera: Tephritidae) with a braconid parasitoid and a novel bait spray. J Econ Entomol 94:817-825

Vörösmarty CJ, McIntyre P, Gessner MO, Dudgeon D, Prusevich A, Green P, Glidden S, Bunn SE, Sullivan CA, Liermann CR (2010) Global threats to human water security and river biodiversity. Nature 467:555-561

Waller JM, Bridge J (1978) Plant diseases and nematodes in the Sultanate of Oman. PANS 24:313-326

Wang B (1995) Interdecadal changes in El Niño onset in the last four decades. J Clim 8:267-285

Wang Z, Yin Y, Hu H, Yuan Q, Peng G, Xia Y (2006) Development and application of molecular-based diagnosis for 'Candidatus Liberibacter asiaticus', the causal pathogen of citrus huanglongbing. Plant Pathol 55:630-638

Watts W, Alam M (1973) Spray trials against the citrus blackfly (Aleurocanthus woglumi) on limes in the Oman. Miscellaneous
Report, Overseas Development Administration, Foreign and Commonwealth Office

Westbrook CJ, Hall DG, Stover E, Duan YP, Lee RF (2011) Colonization of citrus and citrus-related germplasm by $D i$ aphorina citri (Hemiptera: Psyllidae). HortScience 46:997-1005

Wilkes G, Williams J (1983) Current status of crop plant germplasm. Crit Rev Plant Sci 1:133-181

Bolland HR, Gutierrez J, Flechtmann CH (1998) World catalogue of the spider mite family (Acari: Tetranychidae). Brill, Leiden

Frison E, Taher M (1991) FAO/IBPGR technical guidelines for the safe movement of citrus germplasm. Bioversity International, Rome

Yadav AR, Chauhan A, Rekha M, Rao L, Ramteke R (2004) Flavour quality of dehydrated lime (Citrus aurantifolia (Christm.) Swingle). Food Chem 85:59-62

Yang YB, Allen JC, Knapp JL, Stansly PA (1994) Citrus rust mite (Acari: Eriophyidae) damage effects on 'Hamlin' orange fruit growth and drop. Environ Entomol 23:244-247

Yokomi RK, Lastra R, Stoetzel MB, Damsteegt VD, Lee RF, Garnsey SM, Gottwald TR, Rocha-Pena MA, Niblett CL (1994) Establishment of the brown citrus aphid (Homoptera: Aphididae) in Central America and the Caribbean Basin and transmission of citrus tristeza virus. J Econ Entomol 87:1078-1085

Yonow T, Hattingh V, de Villiers M (2013) CLIMEX modelling of the potential global distribution of the citrus black spot disease caused by Guignardia citricarpa and the risk posed to Europe. Crop Prot 44:18-28

Zanek MC, Peña E, Reyes CA, Figueroa J, Stein B, Grau O, Garcia ML (2006) Detection of citrus psorosis virus in the northwestern citrus production area of argentina by using an improved TASELISA. J Virol Methods 137:245-251

Zreik L, Carle P, Bové JM, Garnier M (1995) Characterization of the mycoplasmalike organism associated with witches'-broom disease of lime and proposition of a Candidatus taxon for the organism 'Candidatus phytoplasma aurantifolia'. Int J Syst Bacteriol 45:449-453 